
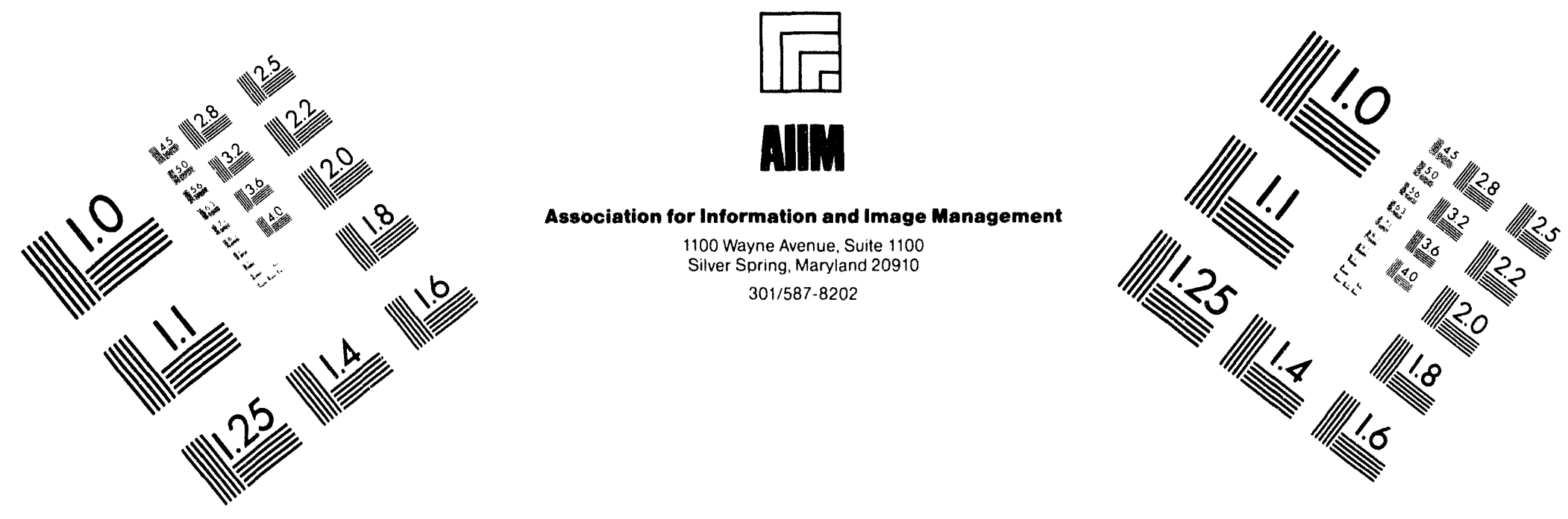

Centimeter

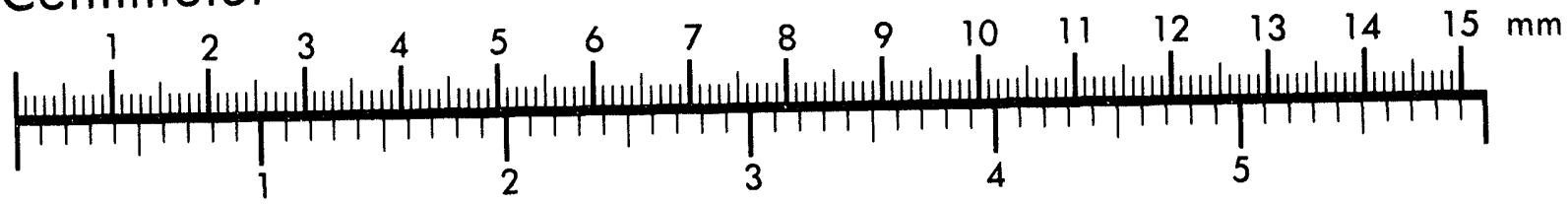
Inches
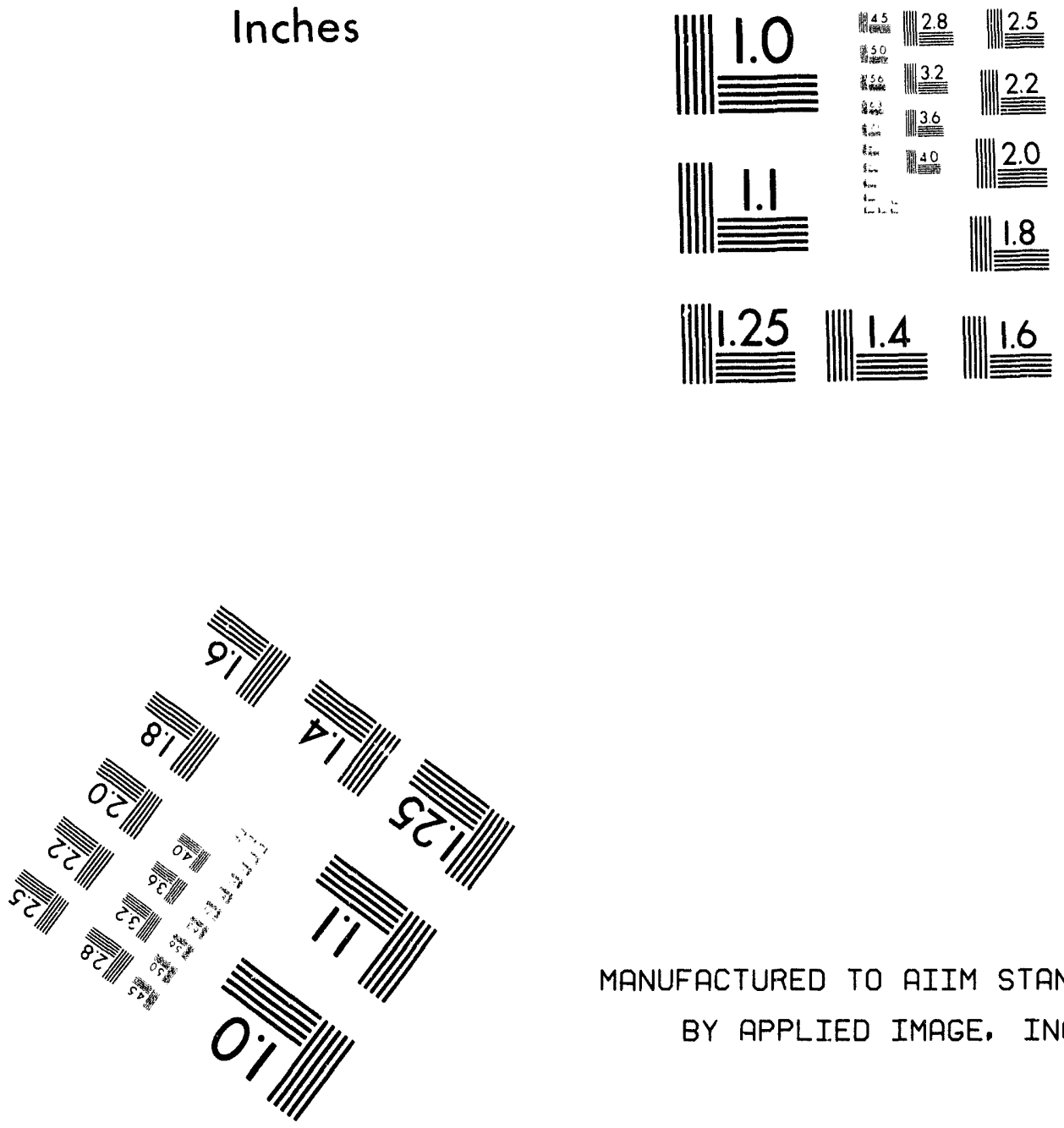

MANUFACTURED TO AIIM STANDARDS BY APPLIED IMAGE, INC.

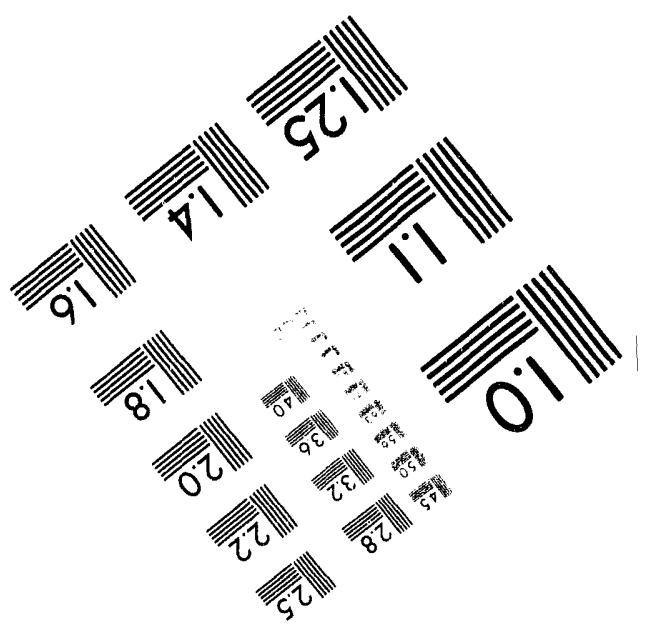



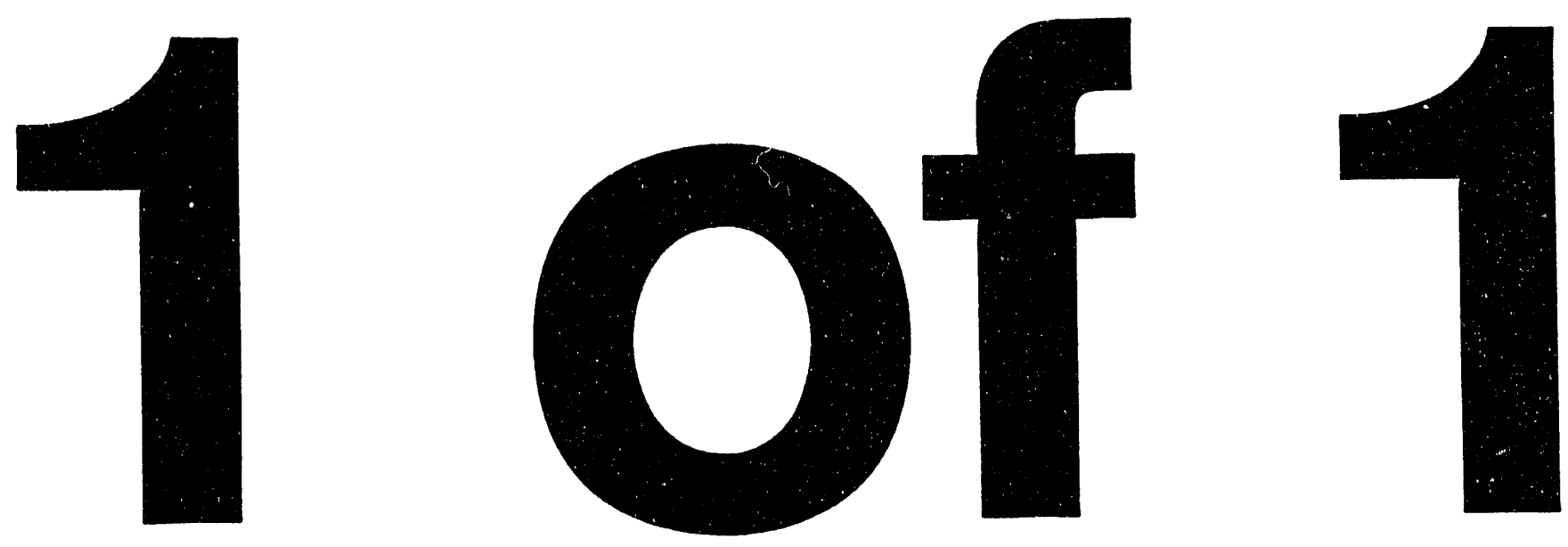
DEPARTMENT OF ENERGY

PROPOSED FINDING OF NO SIGNIFICANT IMPACT FOR THE SAKAKAMEA MEDICAL CENTER COAL-FIRED HEATING PLANT

AGENCY: Department of Energy

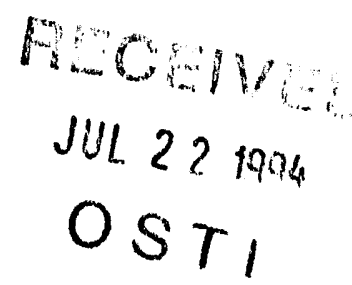

SUMARY: The Department of Energy (the Department) has prepared an environmental assessment (Assessment) (DOE/EA-0949) to identify and evaluate the potential environmental impacts of a proposed action at the Sakakawea Medical Center (the Center) in Hazen, North Dakota. The proposed action would replace the existing No. 2 fuel oil-fired boilers supplemented by electric reheat with a new coal-fired hot water heating $\mathrm{plant}$, using funds provided from a grant under the Institutional Conservation Program.

Based on the analysis in DOE/EA-0949, the Department has determined that the proposed action is not a major federal action significantly affecting the quality of the human environment, within the meaning of the National Environmental Policy Act (NEPA) of 1969, as amended. Therefore, preparation of an Environmental Impact Statement is not required, and the Department is issuing this Finding of No Significant Impact (Finding). 
Comments or requests for copies of the Assessment should be addressed to:

Ms. Marian Downs

Denver Support Office

U. S. Department of Energy

2801 Youngfield St.

Suite 380

Golden, CO 80401-2266

(303) 231-5750 Ext. 129

\section{FOR FURTHER INFORMATION CONTACT:}

For further information on the proposed project, contact Marian Downs at the above address. For further information. on the Department's general NEPA procedures, contact:

Ms. Carol Borgstrom, Director

Office of NEPA Oversight (EH-25)

U.S. Department of Energy

1000 Independence Avenue, S. W.

Washington, DC 20585

(202) 586-4600 or leave a message at (800) 472-2756

SUPPLEMENTARY INFORMATION: The Center is located in Hazen, North Dakota. Hazen is located in Mercer County, in the southwestern part of the state. The property occupies roughly 6 hectares (15 acres); the total area of the building complex is roughly 3,460 square meters $(37,240$ square feet). The original building was constructed in 1969, and there were additions made in 1982. Estimated remaining useful life of the building complex is 60 years.

The current heating system uses a combination of two No. 2 fuel oil-fired boilers and electric reheat. The primary heating plant consists of two Dunham Bush/Iron Fireman Hitirl Power Square Heat Model 35-5.400 boilers. These boilers have an output rating of 2.6 million British thermal units per hour $(\mathrm{Btu} / \mathrm{hr})$, or a nominal 80 boiler HP. Fuel oil consumption is roughly 121,600 liters/year $(32,130$ gallons/year) at a cost of roughly $\$ 26,380$. A 1982 
addition to the Center is heated entirely with electrical reheat units in the ventilation system. As a result, the Center has a large electrical load.

PROPOSED ACTION: The proposed action would involve the following activities:

0 Cost-shared purchase and installation of a $4.5 \mathrm{million}$ Btu/hr coal-fired hot water heating plant.

- Extension of hot water supply and return lines.

- Removal of all electrical reheat units.

- Construction of a 45-90 square meter (500-1000 square foot) building to house the new boiler system; this building would include both a covered bin for coal storage and a covered bin for temporary storage of coal ash pending its pick-up for disposal.

The proposed system would be a completely self-contained, closed-loop system.

The Center would obtain lignite coal from the Knife River Coal mine, located roughly 16 kilometers (10 miles) from Hazen. Coal as fuel for the Center's system was chosen because it is available locally, provides a high Btu value at low cost, and can be stored in greater quantities than can oil. The main disadvantage of coal as a fuel would be an increase in air emissions and the generation of bottom ash waste requiring disposal.

As noted above, the new boiler system would be installed in a 45-90 square meter (500-1000 square foot) building to be constructed adjacent to the hospital structure in an open area owned by the Center. Upon completion of 
the building and installation of the proposed system, the area around the building would remain as open space. The Center plans on retaining the present oil-fired system as a back-up.

ENVIRONMENTAL IMPACTS: The proposed action would result in additional air emissions. A review comparing the proposed action to the existing system was conducted by the North Dakota State Department of Health and Consolidated Laboratories (see Appendix $E$ of the $E A$ ) and concluded that the proposed action would increase emissions above those currently released by the oil-fired furnaces. The present system emits approximately 64 pounds of particulate matter, 2.281 pounds of sulfur oxides, 640 pounds of nitrogen oxides, 161 pounds of carbon monoxide, 11 pounds of non-methane hydrocarbons, and 7 pounds of methane hydrocarbons annually. The proposed system would emit approximately 8,729 pounds of particulate matter, 10,320 pounds of sulfur oxides, 2,580 pounds of nitrogen oxides, 4,730 pounds of carbon monoxide, 559 pounds of non-methane hydrocarbons, and 344 pounds methane hydrocarbons annually. The proposed project would release an unestimated amount of carbon dioxide, a pollutant thought to contribute to global warming. While negligible in terms of the overall combustion of fossil fuels and emissions of carbon dioxide by all fossil-fueled devices, the proposed action would add to any global warming problems that may exist. However, as reported by the North Dakota State Department of Health and Consolidated Laboratories, based on the small quantity of emissions (less than 25 tons per year of any individual air contaminant) the State expects that the proposed system would comply with all applicable State and Federal air pollution control rules. Further, since the proposed system's heat input (approximately $4.5 \times 10^{6} \mathrm{Btu} / \mathrm{hr}$ ) is less than the 
size required to have a permit $\left(10 \times 10^{6} \mathrm{Btu} / \mathrm{hr}\right)$, the new boiler would be exempt from the State requirement to obtain construction and operations permits. With prevailing winds from the northwest, and the facility's location on the eastern edge of Hazen, emissions from the proposed boiler would not pass over the town of Hazen. Although there are three large fossilfuel combustion facilities located 16 miles west of Hazen in Beulah, ND (Great Plains Coal Gasification Plant, Antelope Valley Station, and the Coyote Power Plant), no cumulative impacts on air quality are expected as a result of the proposed action due to the direction of the prevailing winds. Emissions would be carried away from the city, so that cumulative impacts would only occur to the southeast of the city. The nearest town in this direction, Hanover, is more than 20 miles away and has a population of less than 1,000. Because impacts would be limited in duration to the 90 -day construction period and would be mitigated through such appropriate control measures as spraying for dust control, there are no projected impacts from fugitive dust or smoke from construction of the proposed system.

Implementing the proposed action would not affect any natural areas or any wildlife habitats. No vegetation would be cleared during the proposed action's construction phase. No endangered or threatened species would be affected during the proposed action's construction or operational phases. Neither floodplains nor wetlands would be affected by the proposed action. Disturbance of wildlife resulting from noise would be localized and limited to the construction period. Construction activities would not affect wildlife life cycles adversely. Construction debris generated by the proposed action would be disposed of appropriately. 
The proposed action would have no impacts on surface waters. No changes in stormwater runoff quantity or quality are expected. Similarly, the proposed action would have no impact on area groundwater quality. The proposed action is a closed-loop system, so that on a daily basis, no additional water would be needed, and there would be no effluent discharge.

Operating the heating system would generate no hazardous wastes. The approximately 26 tons per year of bottom ash generated would be disposed of at the Hazen City Landfill, which the North Dakota State Department of Health and Consolidated Laboratories has determined is an acceptable facility for the disposal of bottom ash generated by the boilers. In addition to 1 andfill disposal, utilization of this ash (e.g., use as a recycled item for road construction, as a cement component, etc.) is under consideration, with marketability of the ash as the primary limiting factor to this alternative.

Due to the Center's use as a city facility and the limited, localized area of disturbance resulting from construction of the building of the proposed new boiler and later use of the boiler, land use impacts of the proposed action would be minimal. The proposed action would comply with local requirements as an allowed use, as a city facility. Following construction, the area would revert to its original use.

Existing recreational areas (i.e., the small city playground and the school playground that are approximately 300 feet and 2,000 feet away, respectively) would not be affected. There are no public or private recreation sites or trails on the site. Because none have been identified by the North Dakota 
State Historic Preservation Officer, the proposed action would have no impact upon historic or archaeological resources.

Construction would require an estimated work force of 2 to 10 workers to be employed for roughly two months. These jobs would have a small short-term benefit to the area, but no significant changes in area economic, housing, or infrastructure conditions are expected. Increased traffic volume can be accommodated by the existing transportation network. The greatest benefits would be to the Center for reduced energy costs and to the area economy with an increase in local coal demand. The proposed action would not have negative effects on Native American, minority or low income communities.

Increased sound levels would be generated during construction activities associated with the proposed action. While the State has not measured them precisely, the increases are expected to be imperceptible to the nearest residences. Work place noise exposure from the proposed action would be maintained within established State and Federal standards. No negative safety or health impacts to the Center's patients, the nearby school's students, those living in proximity to the Center, students or staff of the nearby school are expected to result from the proposed action or the No Action alternative. Any potential exposure of these individuals would be minimized by a combination of engineering controls and implementation of appropriate safe work practices and procedures. Training programs would be provided to ensure that workers are aware of potential hazards associated with operating the proposed system. Any potential exposure of workers to hazards would be minimized by a combination of engineering controls and implementation of 
appropriate work practices and procedures.

ALTERNATIVES CONSIDERED: The alternatives to the proposed action evaluated in the EA were: 1) No Action; 2) Natural Gas as an Alternative Fuel 3) Propane Gas as an Alternative Fuel; 4) Conversion to Electric Heat; and 5) Conversion to Heating from Solar, Wind, and Geothermal.

The No Action alternative would mean the new coal-fired system would not be installed at the Center. The potential benefits derived from installation of this system would not be realized. The Center would continue operation of the existing oil-fired system and electrical reheat units.

Natural gas as an alternative fuel was not feasible since there are neither public utilities nor private firms that supply natural gas to Hazen. Propane gas as an alternative fuel would not provide the safe, reliable fuel source the Center seeks since propane delivery would be by truck and inclement weather could delay fuel delivery. Also, creating additional storage capacity at the Center for propane would cause other concerns, including insurance issues involved with storage tank location and increased liability and would be more expensive than the proposed action. Conversion to electric heat as an alternative would increase heating costs prohibitively: $\$ 2.64$ per million Btu for coal versus $\$ 16.99$ per million Btu for electricity, since it is more efficient to generate heat on-site than to rely on the existing external power sources which are less efficient than generating heat on-site. Finally, the alternative energy generating technologies from solar, wind, and geothermal energy as an alternative were not practical for the building's 
heating system configuration. For solar heating, the costs of extensive mechanical and structural retrofitting would preclude integration of solar and geothermal energy into the present system. While advances in wind energy technology have been attained, this technology is not yet a competitive resource in many areas of the country and no commercial-scale wind energy installations exist in North Dakota.

DETERMINATION: Based on the analysis in the Environmental Assessment, the Department has determined that the proposed installation of a new coal-fired hot water heating plant at the Center does not constitute a major Federal action significantly affecting the quality of the human environment within the meaning of the NEPA. Therefore, the preparation of an Environmental Impact Statement is not required and the Department is issuing this Finding of No Significant Impact.

Issued at Washington, D.C., this
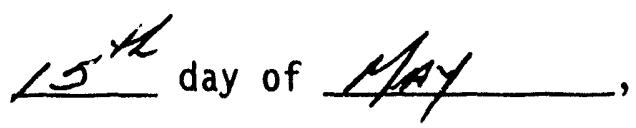
1994.

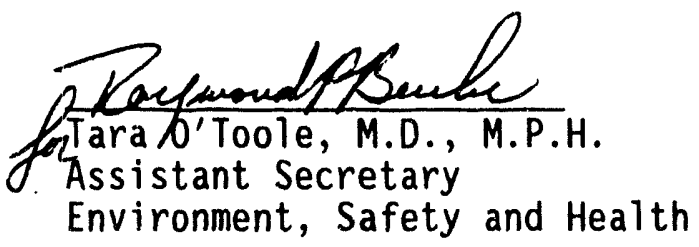


DEPARTMENT OF ENERGY

PROPOSED FINDING OF NO SIGNIFICANT IMPACT FOR THE SAKAKAMEA MEDICAL CENTER COAL-FIRED HEATING PLANT

AGENCY: Department of Energy

ACTION: Finding of No Significant Impact

SUMAARY: The Department of Energy (the Department) has prepared an environmental assessment (Assessment) (DOE/EA-0949) to identify and evaluate the potential environmental impacts of a proposed action at the Sakakawea Medical Center (the Center) in Hazen, North Dakota. The proposed action would replace the existing No. 2 fuel oil-fired boilers supplemented by electric reheat with a new coal-fired hot water heating plant, using funds provided from a grant under the Institutional Conservation Program.

Based on the analys is in DOE/EA-0949, the Department has determined that the proposed action is not a major federal action significantly affecting the quality of the human environment, within the meaning of the National Environmental Policy Act (NEPA) of 1969, as amended. Therefore, preparation of an Environmental Impact Statement is not required, and the Department is issuing this Finding of No Significant Impact (Finding). 
Comments or requests for copies of the Assessment should be addressed to:

Ms. Marian Downs

Denver Support Office

U. S. Department of Energy

2801 Youngfield St.

Suite 380

Golden, CO 80401-2266

(303) 231-5750 Ext. 129

\section{FOR FURTHER INFORMATION CONTACT:}

For further information on the proposed project, contact Marian Downs at the above address. For further information on the Department's general NEPA procedures, contact:

Ms. Carol Borgstrom, Director

Office of NEPA Oversight (EH-25)

U.S. Department of Energy

1000 Independence Avenue, S. W.

Washington, DC 20585

(202) 586-4600 or leave a message at (800) $472-2756$

SUPPLEMENTARY INFORMATION: The Center is located in Hazen, North Dakota. Hazen is located in Mercer County, in the southwestern part of the state. The property occupies roughly 6 hectares (15 acres); the total area of the building complex is roughly 3,460 square meters $(37,240$ square feet). The original building was constructed in 1969 , and there were additions made in 1982. Estimated remaining useful life of the building complex is 60 years.

The current heating system uses a combination of two No. 2 fuel oil-fired boilers and electric reheat. The primary heating plant consists of two Dunham Bush/Iron Fireman Whirl Power Square Heat Model 35-5.400 boilers. These boilers have an output rating of 2.6 million British thermal units per hour (Btu/hr), or a nominal 80 boiler HP. Fuel oil consumption is roughly 121,600 liters/year (32,130 gallons/year) at a cost of roughly $\$ 26,380$. A 1982 
addition to the Center is heated entirely with electrical reheat units in the ventilation system. As a result, the Center has a large electrical load.

PROPOSED ACTION: The proposed action would involve the following activities:

- Cost-shared purchase and installation of a 4.5 million Bt.u/hr coal-fired hot water heating plant.

o. Extension of hot water supply and return lines.

o Removal of all electrical reheat units.

o Construction of a 45-90 square meter (500-1000 square foot) building to house the new boiler system; this building would include both a covered bin for coal storage and a covered bin for temporary storage of coal ash pending its pick-up for disposal.

The proposed system would be a completely self-contained, closed-1oop system.

The Center would obtain lignite coal from the Knife River Coal mine, located roughly 16 kilometers (10 miles) from Hazen. Coal as fuel for the Center's system was chosen because it is available locally, provides a high Btu value at low cost, and can be stored in greater quantities than can oil. The main disadvantage of coal as a fuel would be an increase in air emissions and the generation of bottom ash waste requiring disposal.

As noted abuve, the new boiler system would be installed in a 45-90 square meter (500-1000 square foot) building to be constructed adjacent to the hospital structure in an open area owned by the Center. Upon completion of 
the building and installation of the proposed system, the area around the building would remain as open space. The Center plans on retaining the present oil-fired system as a back-up.

ENVIRONMENTAL IMPACTS: The proposed action would result in additional air emissions. A review comparing the proposed action to the existing system was conducted by the North Dakota State Department of Health and Consolidated Laboratories (see Appendix $E$ of the EA) and concluded that the proposed action would increase emissions above those currently released by the oil-fired furnaces. The present system emits approximately 64 pounds of particulate matter, 2.281 pounds of sulfur oxides, 640 pounds of nitrogen oxides, 161 pounds of carbon monoxide, 11 pounds of non-methane hydrocarbons, and 7 pounds of methane hydrocarbons annually. The proposed system would emit approximately 8,729 pounds of particulate matter, 10,320 pounds of sulfur oxides, 2,580 pounds of nitrogen oxides, 4,730 pounds of carbon monoxide, 559 pounds of non-methane hydrocarbons, and 344 pounds methane hydrocarbons annually. The proposed project would release an unestimated amount of carbon dioxide, a pollutant thought to contribute to global warming. While negligible in terms of the overall combustion of fossil fuels and emissions of carbon dioxide by all fossil-fueled devices, the proposed action would add to any global warming problems that may exist. However, as reported by the North Dakota State Department of Health and Consolidated Laboratories, based on the small quantity of emissions (less than 25 tons per year of any individual air contaminant) the State expects that the proposed system would comply with all applicable State and Federal air pollution control rules. Further, since the proposed system's heat input (approximately $4.5 \times 10^{6} \mathrm{Btu} / \mathrm{hr}$ ) is less than the 
size required to have a permit $\left(10 \times 10^{6} \mathrm{Btu} / \mathrm{hr}\right)$, the new boiler would be exempt from the State requirement to obtain construction and operations permits. With prevailing winds from the northwest, and the facility's location on the eastern edge of Hazen, emissions from the proposed boiler would not pass over the town of Hazen. Although there are three large fossilfuel combustion facilities located 16 miles west of Hazen in Beulah, ND (Great Plains Coal Gasification Plant, Antelope Valley Station, and the Coyote Power Plant), no cumulative impacts on air quality are expected as a result of the proposed action due to the direction of the prevailing winds. Emissions would be carried away from the city, so that cumulative impacts would only occur to the southeast of the city. The nearest town in this direction, Hanover, is more than 20 miles away and has a population of less than 1,000. Because impacts would be limited in duration to the 90-day construction period and would be mitigated through such appropriate control measures as spraying for dust control, there are no projected impacts from fugitive dust or smoke from construction of the proposed system.

Implementing the proposed action would not affect any natural areas or any wildlife habitats. No vegetation would be cleared during the proposed action's construction phase. No endangered or threatened species would be affected during the proposed action's construction or operational phases. ther floodplains nor wetlands would be affected by the proposed action. Disturbance of wildlife resulting from noise would be localized and limited to the construction period. Construction activities would not affect wildlife life cycles adversely. Construction debris generated by the proposed action would be disposed of appropriately. 
The proposed action would have no impacts on surface waters. No changes in stormwater runoff quantity or quality are expected. Similarly, the proposed action would have no impact on area groundwater quality. The proposed action is a closed-10op system, so that on a daily basis, no additional water would be needed, and there would be no effluent discharge.

Operating the heating system would generate no hazardous wastes. The approximately 26 tons per year of bottom ash generated would be disposed of at the Hazen City Landfil1, which the North Dakota State Department of Health and Consolidated Laboratories has determined is an acceptable facility for the disposal of bottom ash generated by the boilers. In addition to landfill disposal, utilization of this ash (e.g., use as a recycled item for road construction, as a cement component, etc.) is under consideration, with marketability of the ash as the primary limiting factor to this alternative.

Due to the Center's use as a city facility and the limited, localized area of disturbance resulting from construction of the building of the proposed new boiler and later use of the boiler, land use impacts of the proposed action would be minimal. The proposed action would comply with local requirements as an allowed use, as a city facility. Following construction, the area would revert to its original use.

Existing recreational areas (i.e., the small city playground and the school playground that are approximately 300 feet and 2,000 feet away, respectively) would not be affected. There are no public or private recreation sites or trails on the site. Because none have been identified by the North Dakota 
State Historic Preservation Officer, the proposed action would have no impact upon historic or archaeological resources.

Construction would require an estimated work force of 2 to 10 workers to be employed for roughly two months. These jobs would have a small short-term benefit to the area, but no significant changes in area economic, housing, or infrastructure conditions are expected. Increased traffic volume can be accommodated by the existing transportation network. The greatest benefits would be to the Center for reduced energy costs and to the area economy with an increase in local coal demand. The proposed action would not have negative effects on Native American, minority or low income communities.

Increased sound levels would be generated during construction activities associated with the proposed action. While the State has not measured them precisely, the increases are expected to be imperceptible to the nearest residences. Work place noise exposure from the proposed action would be maintained within established State and Federal standards. No negative safety or health impacts to the Center's patients, the nearby school's students, those living in proximity to the Center, students or staff of the nearby school are expected to result from the proposed action or the No Action alternative. Any potential exposure of these individuals would be minimized by a combination of engineering controls and implementation of appropriate safe work practices and procedures. Training programs would be provided to ensure that workers are aware of potential hazards associated with operating the proposed system. Any potential exposure of workers to hazards would be minimized by a combination of engineering controls and implementation of 
appropriate work practices and procedures.

ALTERNATIVES CONSIDERED: The alternatives to the proposed action evaluated in the EA were: 1) No Action; 2) Natural Gas as an Alternative Fuel 3) Propane Gas as an Alternative Fuel; 4) Conversion to Electric Heat; and 5) Conversion to Heating from Solar, Wind, and Geothermal.

The No Action alternative would mean the new coal-fired system would not be installed at the Center. The potential benefits derived from installation of this system would not be realized. The Center would continue operation of the existing oil-fired system and electrical reheat units.

Natural gas as an alternative fuel was not feasible since there are neither public utilities nor private firms that supply natural gas to Hazen. Propane gas as an alternative fuel would not provide the safe, reliable fuel source the Center seeks since propane delivery would be by truck and inclement weather could delay fuel delivery. Also, creating additional storage capacity at the Center for propane would cause other concerns, including insurance issues involved with storage tank location and increased liability and would be more expensive than the proposed action. Conversion to electric heat as an alternative would increase heating costs prohibitively: $\$ 2.64$ per million Btu for coal versus $\$ 16.99$ per million Btu for electricity, since it is more efficient to generate heat on-site than to rely on the existing external power sources which are less efficient than generating heat on-site. Finally, the alternative energy generating technologies from solar, wind, and geothermal energy as an alternative were not practical for the building's 
heating system configuration. For solar heating, the costs of extensive mechanical and structural retrofitting would preclude integration of solar and geothermal energy into the present system. While advances in wind energy technology have been attained, this technology is not yet a competitive resource in many areas of the country and no commercial-scale wind energy installations exist in North Dakota.

DETERMINATION: Based on the analysis in the Environmental Assessment, the Department has determined that the proposed installation of a new coal-fired hot water heating plant at the Center does not constitute a major Federal action significantly affecting the quality of the human environment within the meaning of the NEPA. Therefore, the preparation of an Environmental Impact Statement is not required and the Department is issuing this Finding of No Significant Impact.

Issued at Washington, D.C., this

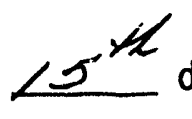
day of 1994.

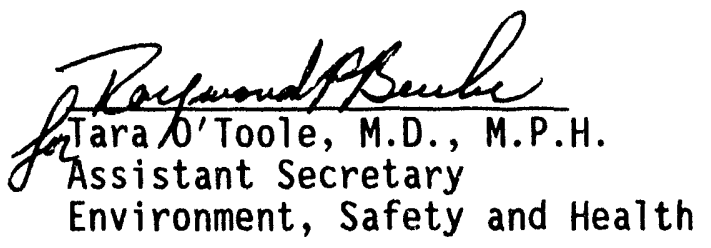




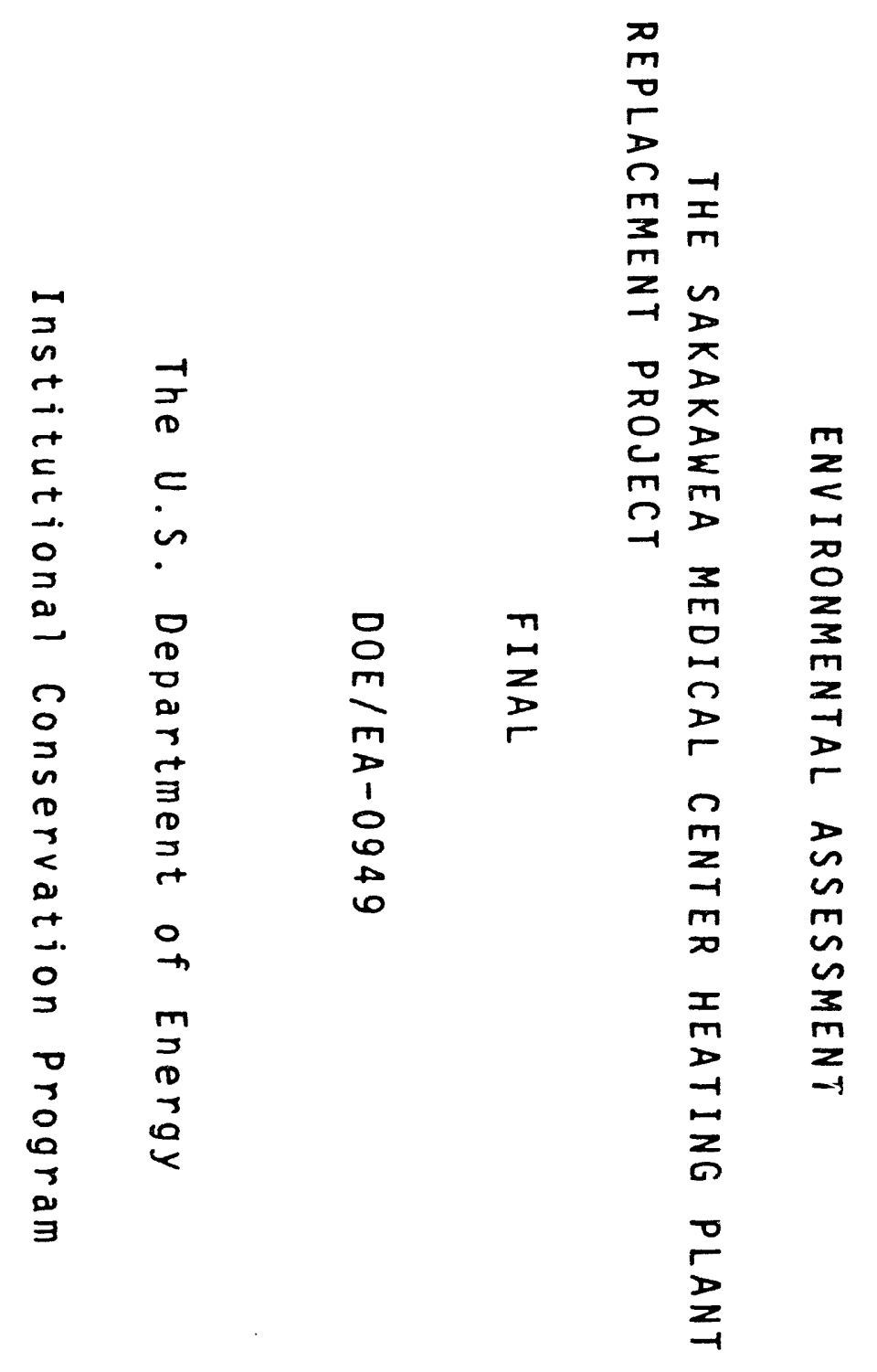




\section{IABLE OF CONTENTS}

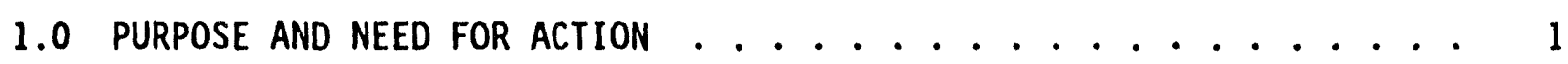

2.0 PROPOSED ACTION AND ALTERNATIVES .................. 2

2.1 The Proposed Action ................. 2

2.2 Alternative Actions ................ 3

2.2.1 Natural Gas as an Alternative Fuel ......... 3

2.2.2 Propane Gas as an Alternative Fuel ......... . 3

2.2.3 Conversion to Electric Heat ........... 3

2.2.4 Conversion to Heating from Solar, Wind, and Geothermal Energy .................... 3

2.3 The No-Action Alternative............... 3

3.0 DESCRIPTION OF AFFECTED ENVIRONMENT . . . . . . . . . . . . 4

3.1 Air Quality.................... 4

3.2 Ecological Resources ................ 4

3.3 Water Quality. .................. 4

3.4 Floodplains and Wetlands .............. 4

3.5 Land Ust ....................... 4

3.6 Visual and Recreational Resources.............. 4

3.7 Historic and Archaeological Resources ............ 4

3.8 Socioeconomics ................. 4

4.0 ENVIRONMENTAL EFFECTS OF PROPOSED ACTION . . . . . . . . . . 5

4.1 Air Quality................... 5

4.2 Ecological Resources ............... 5

4.3 Water Quality ................... 6

4.4 Floodplains and Wetlands .............. 6

4.5 Waste Management .................. 6

4.6 Land Use . . . . . . . . . . . . . . . . . . 6

4.7 Visual and Recreational Resources............. 7

4.8 Historic and Archaeological Resources ........... 7

4.9 Socioeconomics ................. 7

4.10 Noise ...................... 7

4.11 Safety and Health . . . . . . . . . . . . . . 7

4.12 Transportation ................. 7

5.0 LIST OF PERSONS/AGENCIES CONSULTED . . . . . . . . . . . . . 9

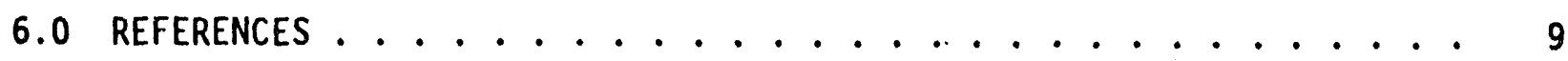

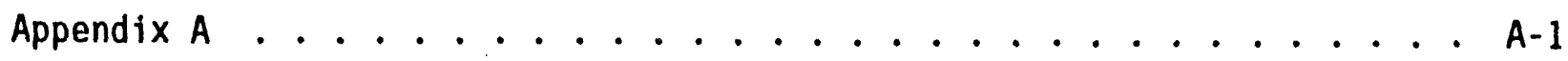


Appendix B ............................ . . B-1

Appendix C . . . . . . . . . . . . . . . . . . . . . C-1

Appendix D . . . . . . . . . . . . . . . . . . . . . . . . D-1

Appendix E . . . . . . . . . . . . . . . . . . . . . . E-1 


\subsection{PURPOSE AND NEED FOR ACTION}

This environmental assessment (EA) analyzes the environmental impacts of replacing the Sakakawea Medical Center's existing oil-fired heating and electrical system with a new coal-fired heating system with funds provided from a grant under the Institutional Conservation Program (the Program). This EA has been prepared in accordance with the provisions of the National Environmental Policy Act, as amended; the Council on Environmental Quality's regulations codified at 40 CFR Parts 1500-1508; the Department of Energy's regulation 10 CFR 1021; Department of Energy Order 5440.1E; and the May 1993 "Recommendations for the Preparation of Environmental Assessments and Environmental Impact Statements, " prepared by the Department of Energy's Office of National Environmental Policy Act Oversight.

The Department's proposed action, as part of the energy conservation program, is to fund 50 percent $(\$ 154,550)$ of the amount required $(\$ 309,100)$ for the installation of a new coal-fired heating system for the Center to replace its existing oil-fired system which would be retained as a back-up system. This environmental assessment has been prepared in connection with the Center's grant application for the $\$ 154,550$ under the Program.

Submitted on January 10, 1992, the Center's application for Departmental grant assistance has been evaluated under applicable Program guidelines. The Center's buildings were evaluated under the Technical Assistance Program Study and Report requirements pursuant to 10 CFR 455.42; these reports were prepared by qualified TA program analysts in accordance with 10 CFR 455.90. The boiler is sized considerably smaller than those requiring review by the U.S. Environmental Protection Agency.

Through the cost-shared Program grant from the Department of Energy, the Center proposes to purchase and install a coal-fired hot water heating system to replace the existing oil-fired system as an energy conservation and operating cost reduction measure. There are distinct advantages to purchasing and installing a new coal-fired system:

- Coal provides a high British thermal unit (Btu) value at a low cost: coal costs roughly $\$ 2.64$ per million Btu, while fuel oil costs $\$ 7.61$ per million $B t u^{2}$. Further, the cost of coal has been relatively stable, while the cost of fuel oil is subject to variability. Use of coal as the fuel source would be consistent with the National Energy Strategy and would help the Center reduce its operating expenditures. The Center anticipates reducing its heating costs by over $\$ 34,000$ a year and realizing simple pay-back for the proposed action within 9.5 years. 
- Use of coal as a fuel would eliminate dependency on domestic and imported oil. This also would be consistent with the National Energy Strategy.

- Substituting a coal-fired system for the present oil-fired one would support a new market for local coal. 


\subsection{PROPOSED ACTION AND ALTERNATIVES}

\subsection{The Proposed Action}

The proposed action would involve the following activities:

- Cost-shared purchase and installation of a 4.5 million Btu/hr coal-fired hot water heating plant.

- Extension of hot water supply and return lines.

- Removal of all electrical reheat units.

- Construction of a building of about 45-90 square meters (500-1000 square feet) to house the new boiler system; this building would include both a covered bin for coal storage and a covered bin for temporary storage of coal ash pending its pick-up for disposal.

The Center is located in Hazen, North Dakota. Hazen, a small community of approximately 2,800 peopla, is located in Mercer County, in the southwestern part of the state. (See Appendix A, Figures 1 and 2.) The property occupies roughly 6 hectares ( 15 acres); the total area of the building complex is roughly 3,460 square meters $(37,240$ square feet). (See Appendix A, Figure 3.) The original building was constructed in 1969, and there were additions made in 1982. The estimated remaining useful life of the building complex is 60 years. See Section 3.6 for additional description of the site.

Appendix A, Figure 3 indicates che location of the proposed action relative to the rest of the medical center complex and the surrounding environment. The proposed system would be a completely self-contained, closed-loop system. Specific details of the action (e.g., size and exact placement of the coal and ash bins, exact routing and placement of supply and return lines, stack height, etc.) will not be known until completion of the project's design phase, which will not occur until the project is approved and a designer is selected and contracted. However, it is expected that construction/installation activities would take approximately 90 days to complete. The center plans on retaining the present oil-fired system as a back-up.

The current heating system uses a combination of two No. 2 fuel oil-fired boilers and electric reheat. The primary heating plant consists of two Dunham Bush/Iron Fireman Whirl Power Square Heat Model 35-5.400 boilers. These boilers have an output rating of 2.6 million British thermal units per hour (Btu/hr), or a nominal 80 boiler HP. Fuel oil consumption is roughly 121,600 liters/year 
$(32,130 \mathrm{gallons} /$ year) at a cost of roughly $\$ 26,380$. The 1982 addition to the Center is heated entirely with electrical reheat units in the ventilation system. As a result, the Center has a large electrical load. Technical analysts determined the Center's electrical heating load was approximately 278,000 kilowatt hours (kWh). With demand charges, associated costs total $\$ 13,750 /$ year. In the current configuration, heating costs for the institution total $\$ 40,130 /$ year.

The Center would obtain lignite coal from the Knife River Coal mine, located roughly 16 kilometers (10 miles) from Hazen. The coal would be delivered to the Center by truck. It is expected that the proposed action would require less than 40 shipments a year of coal to provide the anticipated 429 tons the new system would require. Coal would be stored in a covered bin and auger-fed to the boiler. Ash would be removed by another auger to a wheeled, covered ash bin. It is anticipated that there would be about 26 tons a year of ash for disposal. The ash either would be recycled as a construction material or disposed of in the Hazen landfill, in accordance with state and federal requirements. Disposal would involve transportation of approximately three shipments of ash per year to the landfill.

The choice of coal as fuel for the Center's system offers the advantages of being available within a relatively short distance of Hazen and of providing a high Btu value at low cost ( $\$ 2.64$ per million Btu versus the current $\$ 7.61$ per million Btu for fuel oil). ${ }^{2}$ Further, coal can be stored in greater quantities than can oil, better providing against such contingencies as unpredictable weather which often hamper timely delivery of fuel oil, which must be delivered from a greater distance than coal, which, as noted above, would be obtained locally. The main disadvantage of coal as a fuel would be an increase in air emissions and the generation of bottom ash waste requiring disposal. The air emissions that would be released by the proposed system, as compared with the present system, are shown in Appendix E, Table 1, and are discussed in Section 4.1.

As noted above, the new boiler system would be installed in a building of about 45-90 square meters (500-1000 square feet), to be constructed adjacent to the hospital structure in an open area owned by the Center. Upon completion of the building and installation of the proposed system, the area around the building would remain open space. 


\subsection{Alternative Actions}

2.2.1 Natural Gas as an Alternative Fuel -. This option was not analyzed because there exist no public utilities or private firms for supplying natural gas to Hazen.

2.2.2 Propane Gas as an Alternative Fuel -- Propane is a natural gas substitute with lower heating values. However, this alternative was analyzed and eliminated for several reasons. While propane would create lesser air emissions impacts, its use would not provide the safe, reliable fuel source the Center seeks; there is a greater hazard of fire or explosion, which would place staff and patients in greater jeopardy. In a related vein, creating additional storage capacity at the Center for propane would cause other concerns, including insurance issues involved with storage tank location and increased liability. Since propane delivery would be by truck from a greater distance than the locally available coal for the proposed action, inclement weather could delay fuel delivery, raising questions about the reliability of this fuel source. Finally, when compared to coal, propane is relatively expensive -- a spot market price of $\$ 6.50$ per million Btu, as compared with $\$ 2.64$ per million Btu for coal. ${ }^{2}$

2.2.3 Conversion to Electric Heat -- Conversion to electric heat was analyzed as an alternative but was eliminated from consideration because it is more efficient to generate heat on-site than to rely on the existing external power sources. As shown in Appendix B, to heat the Center, more coal would be burned by off-site power plants than by the proposed action, which would result in greater air emissions. This option would also increase heating costs prohibitively: \$2.64 per million. Btu for coal versus $\$ 16.99$ per million Btu for electricity.

2.2.4 Conversion to Heating from Solar, Wind, and Geothermal Energy -Solar, wind, and geothermal heating also were analyzed and el iminated from consideration. The Center's technical analysts determined that these alternative energy generating technologies were not practical for the building's heating system configuration. For example, for solar heating, the costs of extensive mechanical and structural retrofitting would preclude integration of solar and geothermal energy into the present system. ${ }^{3}$ While advances in wind energy technology have been attained, this technology is not yet a competitive resource in many areas of the country; no commercial-scale wind energy installations exist in North Dakota. 


\subsection{The No-Action Alternative}

If the use of the existing oil-fired system were continued, the new coal-fired system would not be installed at the Center. Continued use of fuel oil was analyzed and eliminated from further consideration because it would not resolve the Center's concerns over escalating heating costs and energy conservation goals. The potential benefits derived from installation of the proposed system would not be realized. The Center would continue operation of the existing oilfired system and electrical reheat units. 


\subsection{DESCRIPTION OF AFFECTED ENVIRONMENT}

\subsection{Air Quality}

Hazen is located in North Dakota Air Quality Control Region 172. As reported by the North Dakota State Department of Health and Consolidated Laboratories (see Appendix E), ambient air quality monitoring data in the Hazen area has indicated that current pollutant levels are well below both federal and state ambient air quality standards. Further, all areas within the state are in attainment with all federal ambient air quality standards (as specified in Chapter 33-15-02, North Dakota Administrative Code; 40 CFR 50, National Primary and Secondary Ambient Air Quality Standards). Prevailing winds in the area are from the northwest.

\subsection{Ecological Resources}

The Center has been in operation for 23 years and the site has been extensively disturbed. The site is adjacent to a parking lot and railroad track. In a notice dated August 18, 1993, the U.S. Fish and Wildlife Service, Fish and Wildlife Enhancement, North Dakota State Office, reported that no federal - or state-listed threatened, endangered, or rare plant or animal or critical habitat is present on the site. Additionally, in a notice dated August 23, 1993, the North Dakota Game and Fish Department reported that the proposed action would have no adverse impacts on wildlife or wildlife habitat, including endangered species. Copies of these notices can be found in Appendix C.

\subsection{Water Quality}

No surface waters cross the site of the proposed action. The nearest surface water to the site is the Knife River, located roughly 90 meters (300 feet) southeast of and across a railroad right-of-way from the site boundary. Hazen receives approximately 15 inches of rain a year.

There is no interaction with either the waterway or groundwater sources. Nothing is drawn from either source, and nothing is introduced into them.

\subsection{Floodplains and Wetlands}

The site of the proposed action is less than 1 meter (roughly 1 foot) above the 100-year floodplain. No wetlands are located within the site boundary. 


\subsection{Land Use}

The Center occupies roughly 6 hectares (15 acres) within the city limits of Hazen, in a region of North Dakota characterized by rolling hills. Construction and operation of the proposed action would occur within the confines of the existing site. No additional lands are required for the proposed action. No prime, unique, or important farmlands are present at the site.

\subsection{Visual and Recreational Resources}

The site is surrounded by parking areas, railroad facilities, and, to the west and north, residential housing. The nearest residents are roughly 90 meters (300 feet) from the site. The nearest public or private recreational areas to the site are a small city playground (approximately 300 feet away) and a school playground (approximately 2,000 feet away).

\subsection{Historic and Archaeological Resources}

The North Dakota State Historic Preservation Officer, in a notice dated August 17, 1993, confirmed that no known resources having historic, architectural, archaeological significance, including Native American burial grounds or sacred use areas, are in the vicinity of the proposed action. A copy of this notice is provided in Appendix $D$.

\subsection{Socioeconomics}

Given the small size of the construction and operations work force and the small likelihood of socioeconomic effects from the proposed action, a socioeconomic profile of the Hazen region is not included in this EA.

There are no Native American tribes, low income or minority communities in proximity to the Hazen site. Three affiliated tribes of Native Americans closest to the proposed site are 18 miles northwest and up. 


\subsection{ENVIRONMENTAL EFFECTS OF PROPOSED ACTION}

\subsection{Air Quality}

Because they would be limited in duration to the 90-day construction period and would be mitigated through such appropriate control measures as spraying for dust control, there are no projected impacts from fugitive dust or smoke from construction of the proposed system.

Operation of the proposed system would result in additional air emissions. A review comparing the proposed action to the existing system was conducted by the North Dakota State Department of Health and Consolidated Laboratories.' This review was conducted under the North Dakota Air Pollution Control Program, which has been approved by EPA. The results of this review are presented in Appendix $E$, including a table comparing emissions of the present and the proposed systems. In summary, the North Dakota State Department of Health and Consolidated Laboratories reported the following:

The present system emits approximately 64 pounds of particulate matter, 2,281 pounds of sulfur oxides, 640 pounds of nitrogen oxides, 161 pounds of carbon monoxide, 11 pounds of non-methane hydrocarbons, and 7 pounds of methane hydrocarbons annually.

The proposed system would emit approximately 8,729 pounds of particulate matter, 10,320 pounds of sulfur oxides, 2,580 pounds of nitrogen oxides, 4,730 pounds of carbon monoxide, 559 pounds of non-methane hydrocarbons, and 344 pounds methane hydrocarbons annually.

The proposed project would release an unestimated amount of carbon dioxide, a pollutant thought to contribute to global warming. While negligible in terms of the overall combustion of fossil fuels and emissions of carbon dioxide by all fossil-fueled devices, the proposed action would add to any global warming problems that may exist.

Based on projected emissions associated with the proposed action, it is expected that the proposed facility would comply with all applicable federal and state air pollution control rules.

While the proposed action would increase emissions above those currently released by the oil-fired furnaces, the overall impact to air quality from implementing the proposed action is expected to be minor. 
The proposed system would be exempt from the North Dakota requirement to obtain a Permit to Construct and Permit to Operate since its rated heat input -- roughly $4.5 \times 10^{6} \mathrm{Btu} / \mathrm{hour}$.- is less than the size required to have a permit - $10 \times 10^{6} \mathrm{Btu} / \mathrm{hour}$-. and actual emissions would be less than 25 tons/year of any air contaminant.

With prevailing winds from the northwest, and the facility's location on the eastern edge of Hazen, emissions from the proposed boiler would not pass over the town of Hazen (see Appendix A, Figures 1 and 2). Although there are three large fossil-fuel combustion facilities located 16 miles west of Hazen in Beulah, ND (Great Plains Coal Gasification Plant, Antelope Valley Station, and the Coyote Power Plant), no cumulative impacts on air quality are expected as a result of the proposed action due to the direction of the prevailing winds. Emissions would be carried away from the city, so that cumulative impacts would only occur to the southeast of the city. The nearest town in this direction, Hanover, is more than 20 miles away and has a population of less than 1,000.

Under the No-Action alternative, the oil-fired system presently in operation at the center would continue to operate until the system reached the end of its useful life. Current emissions levels would continue, as indicated in the text above and illustrated in Table 1, Appendix $E$, and cause no additional impact on air quality.

\subsection{Ecological Resources}

Implementing the proposed action would not affect any natural areas or any wildlife habitats. No vegetation would be cleared during the proposed action's construction phase. No endangered or threatened species would be affected during the proposed action's construction or operational phases. Disturbance to wildlife resulting from noise would be localized and limited to the construction period. Construction activities would not affect wildl ife life cycles adversely.

Under the No-Action alternative, there is not likely to be any impact on ecological resources, as no modification of the present medical center facility would be necessary until the present system had to be replaced.

\subsection{Hater Quality}

No surface waters cross the site of the proposed action and the nearest surface water to the site is roughly 90 meters ( 300 feet). The proposed action would have no impacts on surface waters. No changes in stormwater runoff quantity or quality are expected. 
Similarly, the proposed action would have no impact on area groundwater quality. Coal and ash storage in closed containers virtually would eliminate the danger of leachate entering local groundwaters - any accidental spillage of coal or ash during loading/unloading operations, although not specifically quantifiable, would be expected to be small and inconsequential.

The proposed action would be a closed-loop system. It would be filled once, using roughly 3,785 liters (1,000 gallons) of city water. On a daily basis, no additional water would be needed. Since this is a closed-loop system, there would be no effluent discharge.

Under the No-Action alternative, there would be no changes in the local water quality, as the present system would remain in operation.

\subsection{Floodplains and Wetlands}

Neither floodplains nor wetlands would be affected by the proposed action.

Under the No-Action alternative, there would be no floodplain/wetlands impacts, as the present system would remain in operation.

\subsection{Waste Management}

Construction debris generated by the proposed action would be disposed of at the Hazen City Landfill or as otherwise appropriate, in accordance with local, state, and federal requirements.

Operating the heating system would generate no hazardous wastes.4 The North Dakota State Department of Health and Consolidated Laboratories estimated the heating system would generate roughly 23.6 metric tons/year (26 tons/year) of bottom ash. This ash would be transported by truck (approximately three shipments per year) and disposed of at the Hazen City Landfill, which the North Dakota State Department of Health and Consolidated Laboratories has determined is an acceptable facility for the disposal of bottom ash generated by the heating system. This landfill is regulated under section 33.20 of the North Dakota Administrative Code. The Center proposes to contract for management of this ash. The Hazen landfill takes in approximately 1,275 tons per year; the approximately 26 tons of bottom ash from the Center would increase this amount by about 2 percent per year. The landfill has sufficient capacity for another 20-30 years; in the event it were to be closed, there are alternate landfill sites within the region. In addition to landfill disposal, utilization of this ash (e.g., use as a recycled item for road construction, as a cement component, etc.) is under consideration, with marketability of the ash as the primary limiting factor to 
this alternative.

Under the No-Action alternative, no hazardous wastes would be generated and no construction resulting in construction wastes would be required.

\subsection{Land Use}

Land use impacts of the proposed action would be minimal due to the present uses of the site and the limited localized area of disturbance (see Appendix A, Figure $3)$. The proposed action would comply with local requirements as an allowed use, as a city facility. Following construction, the area would revert to its original use.

Under the No-Action alternative, there would be no land use impacts, as the current 1 and use of the area would not be changed.

\subsection{Visual and Recreational Resources}

Upon completion of the proposed action's construction phase, the final appearance of the small building housing the new boiler would be consistent with the existing medical center complex and the character of the surrounding area. Existing recreational areas (i.e., the small city playground and the school playground that are approximately 300 feet and 2,000 feet away, respectively) would not be affected. There are no public or private recreation sites or trails on the site.

Under the No-Action alternative, there would be no impacts on visual or recreational resources, as there would be no changes to the present medical center's physical appearance.

\subsection{Historic and Archaeological Resources}

No historic or archaeological sites have been identified by the North Dakota State Historic Preservation Officer; thus, neither the proposed action nor the No-Action alternative would have any impact upon historic or archaeological resources.

\subsection{Socioeconomics}

Construction would require an estimated work force of 2 to 10 workers to be employed for roughly two months. Given the size of the community, these jobs would have a small short-term benefit to the area, but no significant changes in area economic, housing, or infrastructure conditions are expected. Increased 
traffic volume can be accommodated easily by the existing transportation network.

No effects on Native American, low income or minority communities would be expected.

Operation would result in the creation of one part-time job. The most significant benefits would be reduced energy costs to the Center and an increase in local coal demand.

Under the No-Action alternative, there would be no socioeconomic impacts, although employment that might occur under the proposed action (from area construction firms and the single permanent part-time job) would be foregone.

\subsection{Noise}

Increased sound levels would be generated during construction activities associated with the proposed action. The nearest residence is roughly 90 meters (300 feet) from the site. Because of the limited construction activities, the nature of the site, and the distance to residences, the net increase in noise attributable to construction would be imperceptible. Further, any construction activities would be limited to standard working hours. Because they are expected to be very minor, the precise levels of these increased temporary noise levels were not measured.

Once operational, noise associated with the proposed action would be at levels imperceptible to surrounding residences. Work place noise exposure from the proposed action would be maintained within established State and Federal standards.

\subsection{Safety and Health}

No negative safety or health impacts to the Center's patients, the nearby school's students, those living in proximity to the Center, or students or staff of the nearby school are expected to result from the proposed action or the No Action alternative. Any potential exposure of these individuals would be minimized by a combination of engineering controls and implementation of appropriate safe work practices and procedures. Training programs would be provided to ensure that workers are aware of potential hazards associated with operating the proposed system.

Under the No-Action alternative, there would be no negative occupational or public safety and health impacts, as the present system would remain in use, including continued protection against potential worker exposure to hazards 
through the use of engineering controls and implementation of appropriate work practices and procedures.

\subsection{Transportation}

It is expected that the proposed action would generate an insignificant number of vehicles during either its construction or operational phases. Further, because of low traffic projections, motor vehicle emissions would be insignificant.

Construction activities could result in an estimated increase of two to four vehicles daily. This small increase in traffic volume can easily be accommodated by the existing transportation network.

Because operating the proposed coal-fired boiler would create less than 1 new permanent job, the only traffic impacts would be those associated with shipments of coal from the mine to the Center. Using ten-ton trucks, it is expected that the proposed action would require less than 40 shipments/year of coal to provide the anticipated 429 tons the new system would require. Based on information in section 5.5 of this EA, three shipments of ash per year are projected. This small increase in traffic volume can easily be accommodated by the existing transportation network.

Under the No-Action alternative, there would be no additional transportation impacts, as the present system, which requires approximately 7 shipments a year of between $6,000-7,000$ gallons of No. 2 fuel oil, would remain in use. 


\subsection{LIST OF PERSONS/AGENCIES CONSULTED}

- North Dakota Office of Intergovernmental Assistance

- North Dakota Historical Society

o North Dakota Department of Health and Consolidated Laboratories

- North Dakota Department of Game and Fish

o U.S. Fish and Wildlife Service

o Prairie Engineering

o Hazen City Planner

\subsection{REFERENCES}

1. Letter Report, February 8, 1993, from Tom Bachman, North Dakota Department of Health and Consolidated Laboratories, Environmental Health Section, to Michael Mahlum, North Dakota Office of Intergovernmental Assistance, Institutional Conservation Program.

2. Office of Intergovernmental Assistance (OIA) Surveys (February 1993).

3. "Technical Assistance Report, " Prairie Engineering (December 1992, amended January 1993).

4. U.S. Environmental Protection Agency, "Additional Information on Wastes Studied in the Report to Congress on Wastes from the Combustion of Coal by Electric Utility Power Plants," 58 FR 8273 (1993). 
Appendix A

A-1 


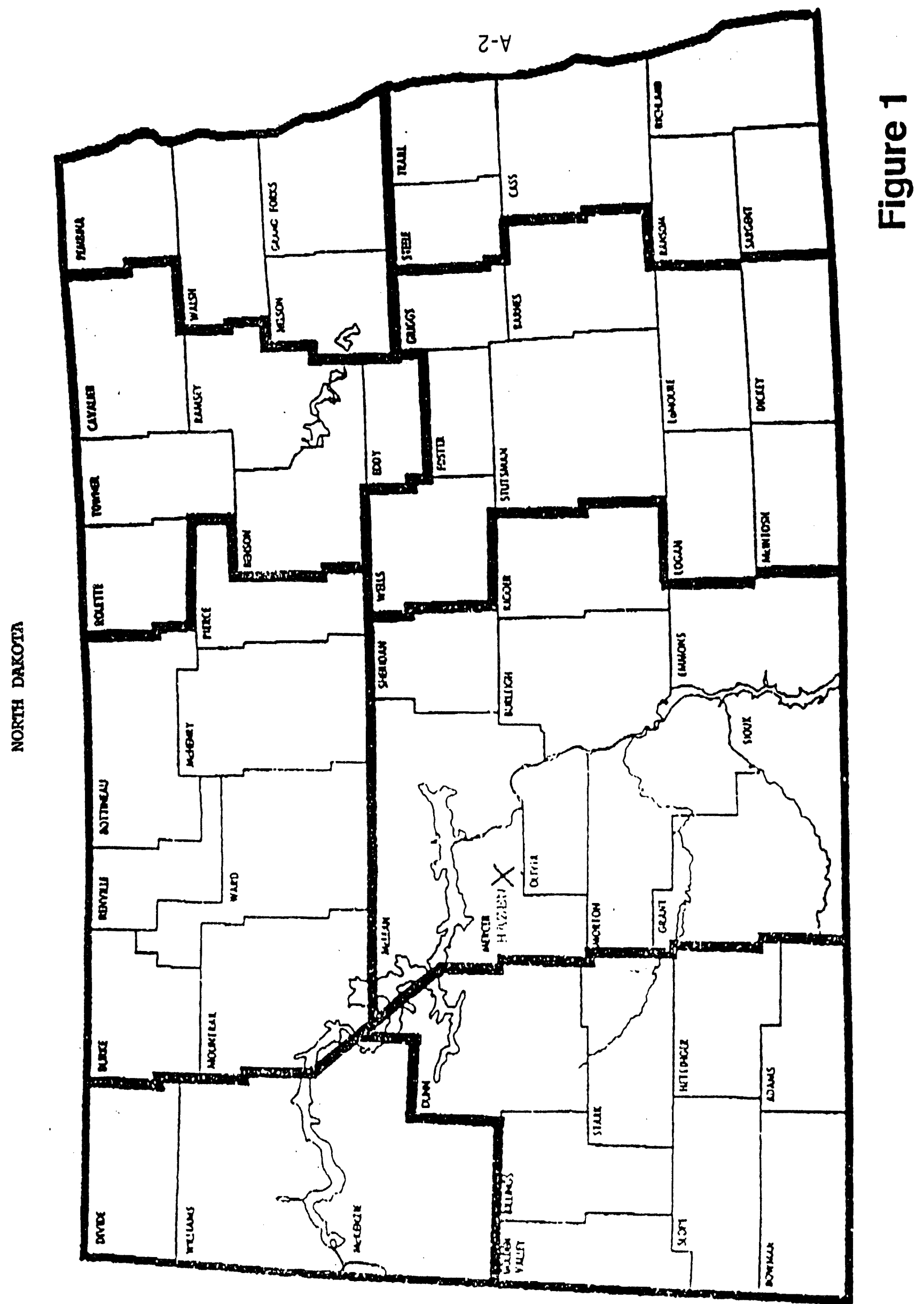


Hazen, North Drasta

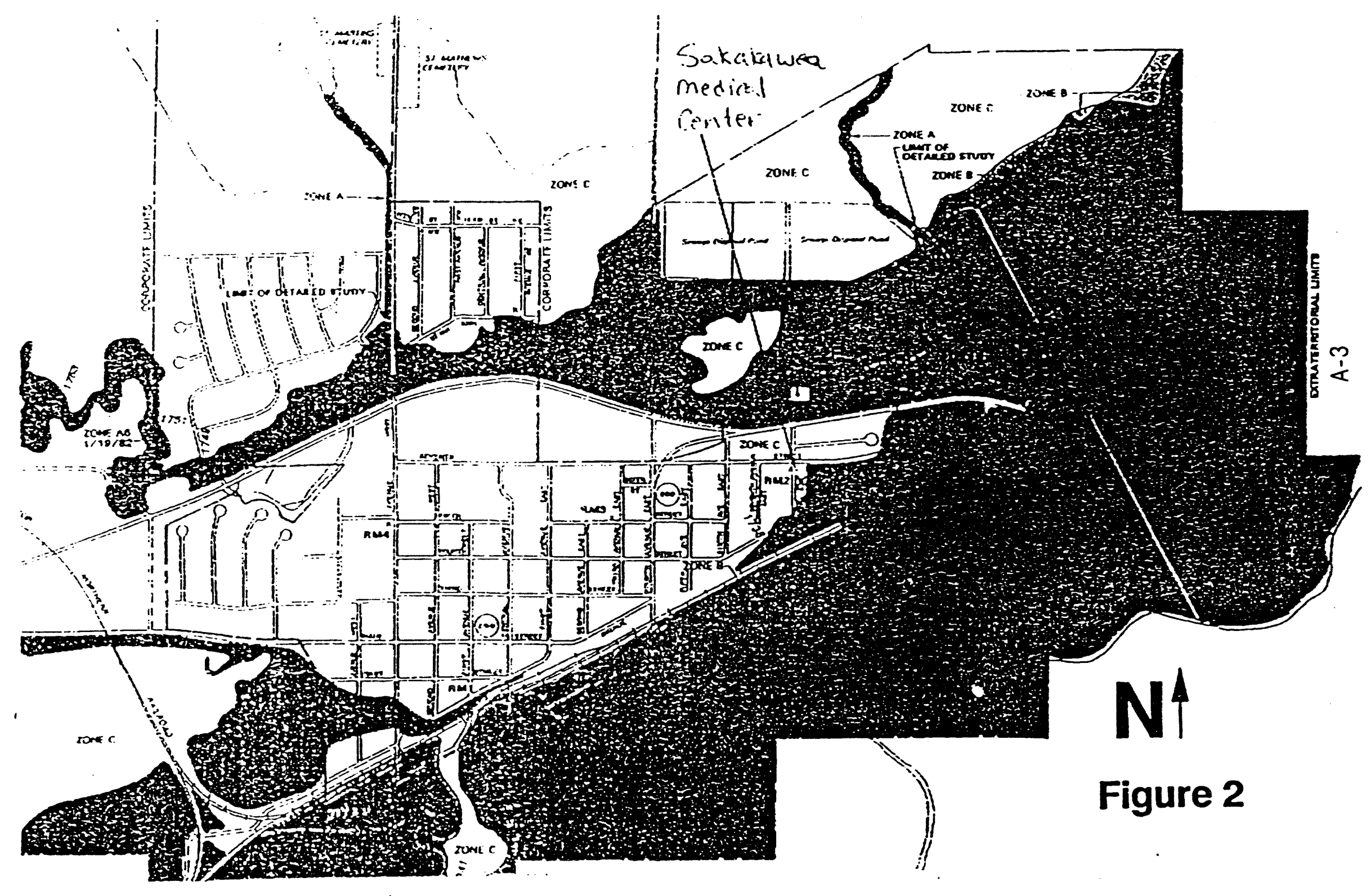




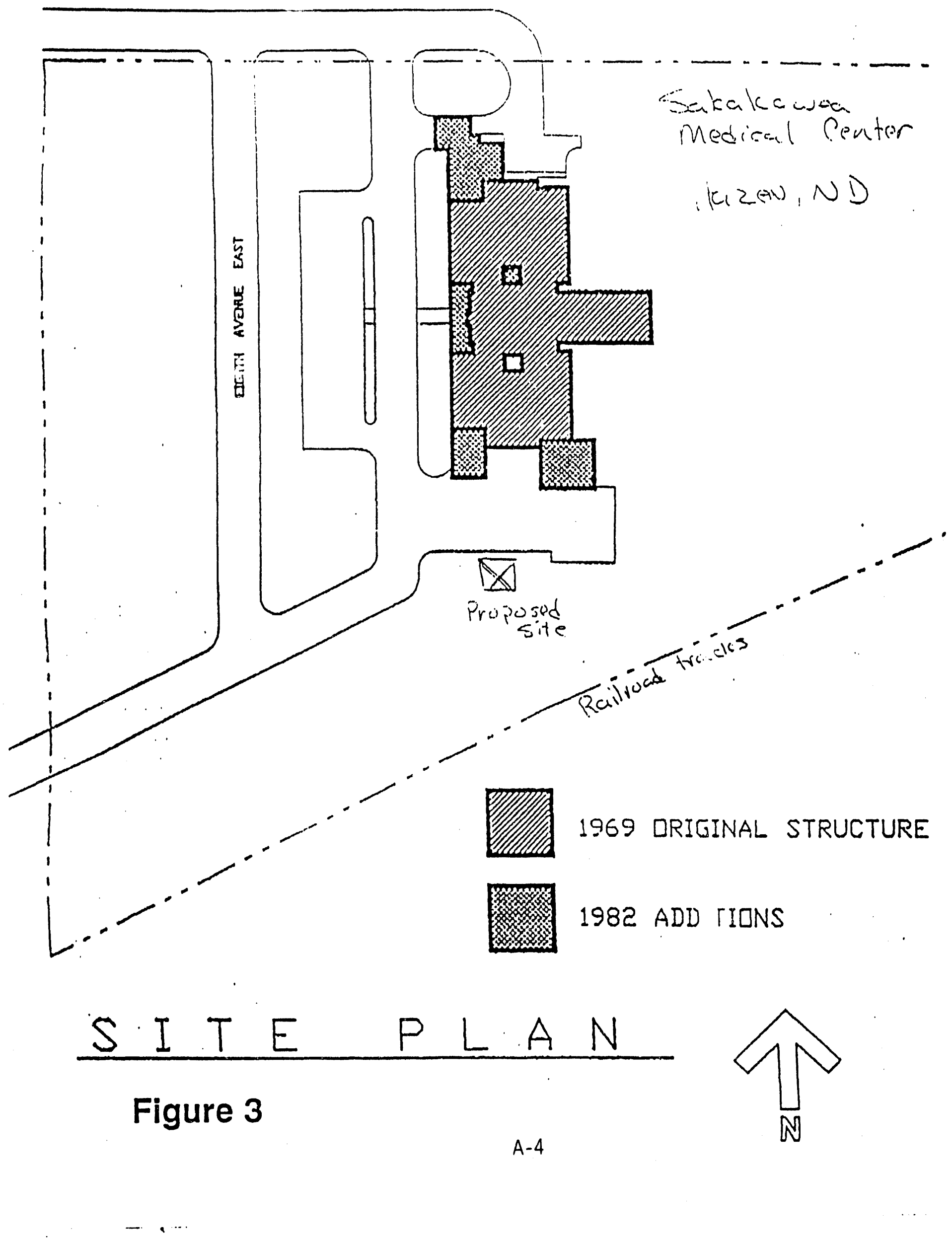




\section{Appendix B}

\section{Heating System Conversions}

As discussed in section 2.2.3, when comparing on-site heating to reliance on external sources of electricity, a distinct advantage of the proposed action is that less coal would be burned to generate the necessary energy to heat the Center. Burning coal onsite requires that 1.33 Btus of heat be generated for each Btu of heat input to the hot-water heating system at a boiler efficiency of 75 percent. Burning coal off-site requires that four Btus of heat be generated for each Btu of heat delivered by an electrical resistance heating system. The energy losses inherent in an off-site power plant, long distance transmission lines, and on-site electrical system are due to efficiency of these systems ( 35 to 40 percent, 85 percent, and 85-90 percent, respectively), for an overall efficiency of approximately 25 percent. 
Appendix C

Response of the U.S Fish and Wildlife Service,

Fish and Wildlife Enhancement, North Dakota State Office

and

Response of the North Dakota Game and Fish Department 
U.S. Fish \& Wildilfe Service

Fish \& Wildlife Enhancement ND State Offlce

Prolect as described will have no signiflcant impact on fish and wildilfe resnurces. No endangered or threatened specles are known to occupy the project area. IF PROJECT DESIGN CHANGES ARE MADE PLEASE SUBMIT PLANS FOR REVIEN.

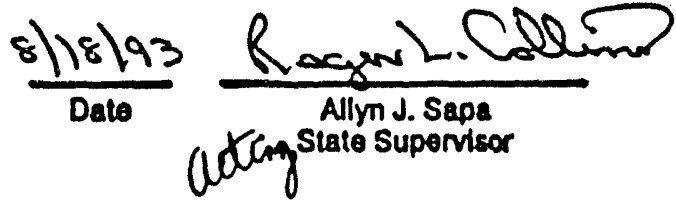


A Division of the Office of Management and Budget

14th Floox - Glate Capitol

BCO Eart Boulevard Avenue

Blemarck. ND 88608.0170

Telepbone (701) 224-2094

FAX (701) 224-2908

TDD (701) $224 \cdot 2404$

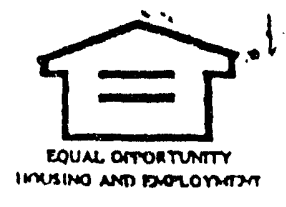

\section{MEMOR A N D U M}

TO: Allan Sapa, State Supervisor
US Fish and Wildlife Service

FROM: Michael Mahlum, Program Administrator
Office of Intergovemmental Assistanc

DATE: August 16, 1993

RE: $\quad$ Hazen Institutional Conservation Program (ICP) Project

As I mentioned to you in our conversation this morning, I've been working with the Sakakawea Medical Center in Hazen, which has been awarded a grant to install a coal-fired boiler system at their facility.

Before final funding approval can be issued by the US. Department of Energy, the institution had to submit an environmental assessment to DOE. The EA which was submitted to DOE was provided to Analytical Services, Inc., a Maryland consulting firm which provided input into additional information which would be necessary for DOE approval.

In particular, they felt that the project should be submitted to the US Fish and Wildife Service for a letter confirming whether the site provides habitat for any federal or state listed, threatened, endangered, or rare plants or animals, or if critical habitat is present on the site.

$\vdots$

I have included a map showing the proposed project location, which is in the City of Hazen. The plans are to build a steel building of 500-1,000 square feet to house a boiler and coal bin. The proposed location has been previously disturbed, and is located directly adjacent to a parking lot and railroad track. No prominent vegetation will be removed.

To the best of my knowledge, the proposed activity will have no impact on any protected species due to the site's previously disturbed nature. It will not create any apparent hazard to the wildlife, since presently paved access will be used. It would be unlikely to create a habitat for any pest species, and will not affect runoff.

Could you please notify me if the site has any such critical habitat or is likely to affect any endangered species?

If you need additional information, please call me at 224-2094.

df

Enc. 
DATE: $\quad$ August 23, 1993

T0: Michael Mahlum, Program Administrator Office of Intergovernmental Assistance

FROM: Michael McKenna, Chief lePP Natural Resources Division

SUBJECT: Hazen Institutional Conservation Program (ICP) Project

The North Dakota Game and Fish Department has reviewed this project and believes that the proposed developinents will have 110 adverse impacts on wildlife or wildlife habitat, including endangered species.

$1 r$ 
Appendix D

Response of the North Dakota State Historical Society

D-1 


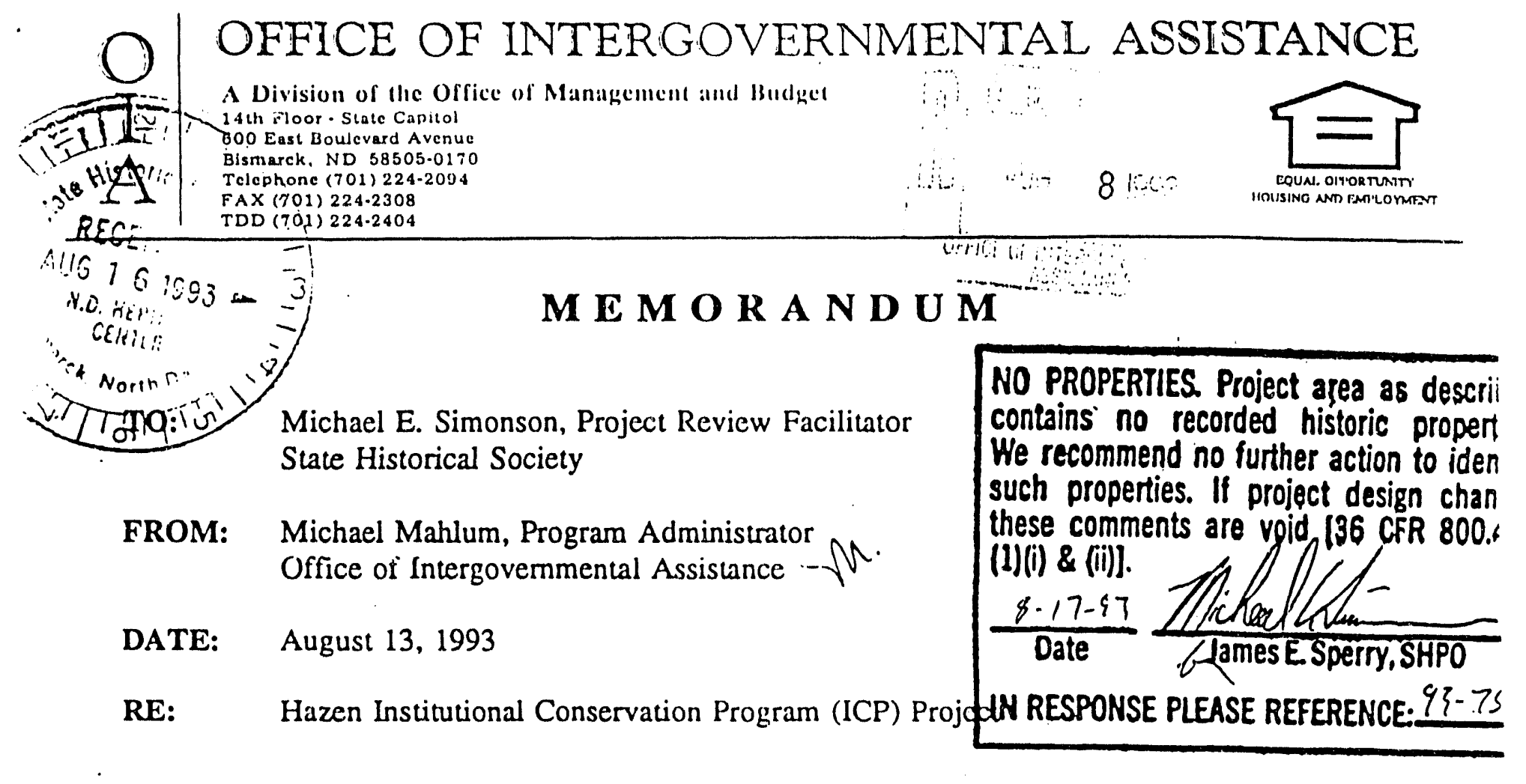

I've been working with the Sakakawea Medical Center in Hazen, which has been awarded a grant to install a coal fired boiler system at their facility.

Before final funding approval can be issued by the US Department of Energy, the institution had to submit an environmental assessment to DOE. The EA which was submitted to DOE was provided to Analytical Services, Inc, a Maryland consulting firm which provided input into additional information which would be necessary for DOE approval.

In particular, they felt that the project should be submitted to the State Historic Preservation Officer for a letter confirming whether there were any known resources having historic, architectural, or archaeological significance, including Native American burial grounds or sacred use areas, which would be affected by the proposed action.

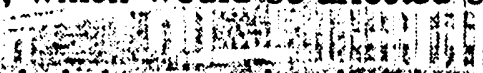
I have included a map showing the proposed project location, which is in the Gity of Hajen. The plans are to build a steel building of $500-1,000$ square feet to house a boiler and coal bin. The proposed location has been previously disturbed and landscaped, and is located directly adjacent to a parking lot and railroad track.

To the best of my knowledge, there are no properties in the vicinity listed on the National Register of Historic Places, the proposed site is not associated with events which were historically significant or the lives of any people of historical significance, is absent of any structures, seems unlikely to yield historical or prehistorical information or history due to its previously disturbed nature, or is not part of any such historic district.

Could you please notify me if the site has any such historic significance? If you need additional information, please call me at 224-2094.

df

Enc. 
Appendix E

$\checkmark$

Response of the North Dakota State

Department of Health and Consolidated Laboratories

$E-1$ 


(1)

February 8,1993
Mr. Mike Mahlum
offlce of Intergovernmental
Assistance
Instltutional Conservation
Program (ICP)

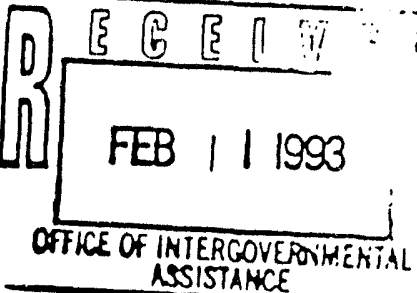

Re: Sakakawea Medical Center

Dear Mr. Mahlum:

Enclosed is a draft section of the environmental assessment for the proposed coal-fired boller at the Sakakawea Medical Center. This portion of the assessment addresses alr pollution, solld waste (bottom ash), and asbestos.

If you have any questions, please call me.

sincerely,

Tom Bachman

Tom Bachman, P.E.

Manager

Alr Quality Management Branch

D1v. of Environmental Engineering

TB : dgg

Enc: 
The new coal-fired boiler system inil result in alr contaminants being emitted and ash generated. A review was conducted to compare emissions of the existing boller system with those from the new coal-fired boiler. The review was conducted by the North Dakota Air Pollution control Program which is approved by the U.S. EPA. Details are summarized in Table 1. The results show a coal-fired furnace would increase emissions above those currently released by the fuel oll furnaces. The new coal-fired boller will be exempt from the ND requirement to obtain a Permit to Construct and Permit to Operate since 1 ts rated heat input (approximately $4.5 \times 10^{6}$ $\mathrm{BTU} / \mathrm{hr})$ is less than the size required to have a permit $\left(10 \times 10^{6}\right.$ BTU/hr) and actual emissions will be less than 25 tons per year of any air contaminant.

Ambient air quality monitoring data in the Hazen area has indicated that the level of air contaminants is weil below the state and Federal Ambient AIr Quality Standards. The state Ambient Alr Quality standards are at least as stringent as the Federal standards. The entire state of North Dakota $1 \mathrm{~s}$ in attainment with all Federal Ambient Alr Quality Standards. Based on the small quantity of emissions, the ND state Department of Health (AII Pollution Control Program) expects that the facility will comply with all applicable State and Federal Air Pollution Control Rules. The minor amount of emissions is unlikely to cause any adverse effects on plants and animals. The project will release a small amount of carbon dioxide, a gas which is thought to contribute to global warming. However, the overall impact to alr quality from installing the proposed coal-fired furnace is expected to be minor.

Assuming an ash content of 7 percent of the coal, burning 430 tons of lignite per year (based on the Medlcal Center current energy usage for heat) would produce approximately 26 tons per year of bottom ash. The Health Department's Solid Waste Management Program regulates the disposal of this material in municipal solid waste landfills in North Dakota. Proper disposal of the coal ash in an approved landf1ll would prevent degradation of solls, surface water quality, and groundwater quality. The landfill at Hazen, North Dakota is an acceptable facility for the disposal of the bottom ash generated from the proposed coal-fired furnace.

The Sakakawea Medical Center has removed all asbestos-containing material from their facility. Therefore, the disturbance of asbestos material during the installation of the boller is not of concern. 
TABLE 1

SAKAKAWEA MEDICAL CENTER

Air Contaminant Emissions

(pounds per year)

\begin{tabular}{|c|c|c|c|c|c|c|}
\hline \multirow[b]{2}{*}{ Fue 1} & \multirow[b]{2}{*}{$\begin{array}{l}\text { Particulate } \\
\text { Matter }\end{array}$} & \multirow[b]{2}{*}{$\begin{array}{l}\text { Sulfur } \\
\text { Oxides } \\
\end{array}$} & \multirow[b]{2}{*}{$\begin{array}{l}\text { Nitrogen } \\
\text { oxides } \\
\end{array}$} & \multirow{2}{*}{$\begin{array}{c}\text { Carbon } \\
\text { Monoxide }\end{array}$} & \multicolumn{2}{|c|}{ Hydrocarbons ${ }^{3}$} \\
\hline & & & & & Nonmethane & Methane \\
\hline $\begin{array}{l}\text { Fuel o11 System } \\
\text { (present usage) }\end{array}$ & 64 & 2,281 & 640 & 161 & 11 & 7 \\
\hline Coal-F1red System & 8,729 & 10,320 & 2,580 & 4,730 & 559 & 344 \\
\hline
\end{tabular}

1. Based on an average ash content of 78 (as recelved)

2. Based on an average sulfur content of 0.88 . (as received) for coal and 0.58 ior oll.

3. Based on use of an underfeed stoker. 
U.S. Fish \& Wildilfe Service

Fish \& Wildlife Enhancement NO State Office

Project as described will have no signiflcant impact on fish and wildile rescurces. No endangered or inreatened species are known to occupy tho project area. IF PROJECT DESIGN CHANGES ARE MADE PLEASE SUBMIT PLANS FOR REVIK

8)18193 Racens SDlom

Date Alim J. Sapa a Jem state suporviser 


\section{ME M OR A N D U M}

TO: $\quad$ Allan Sapa, State Supervisor US Fish and Wildlife Service

FROM: Michael Mahlum, Program Administrator Office of Intergovernmental Assistance

DATE: $\quad$ August 16, 1993

RE: Hazen Institutional Conservation Program (ICP) Project

As I mentioned to you in our conversation this morning, I've been working with the Sakakawea Medical Center in Hazen, which has been awarded a grant to install a coal-fired boiler system at their facility.

Before final funding approval can be issued by the US. Department of Energy, the institution had to submit an environmental assessment to DOE. The EA which was submitted to DOE was provided to Analytical Services, Inc., a Maryland consulting firm which provided input ịto additional information which would be necessary for DOE approval.

In particular, they felt that the project should be submitted to the US Fish and Wildlife Service for a letter confirming whether the site provides habitat for any federal or state listed, threatened, endangered, or rare plants or animals, or if critical habitat is present on the site.

I have included a map showing the proposed project location, which is in the City of Hazen. The plans are to build a steel building of 500-1,000 square feet to house a boiler and coal bin. The proposed location has been previously disturbed, and is located directly adjacent to a parking lot and railroad track. No prominent vegetation will be removed.

To the best of my knowledge, the proposed activity will have no impact on any protected species due to the site's previously disturbed nature. It will not create any apparent hazard to the wildlife, since presently paved access will be used. It wo 'd be unlikely to create a habitat for any pest species, and will not affect runoff.

Could you please notify me if the site has any such critical habitat or is likely to affect any endangered species?

If you need additional information, please call me at 224-2094.

df

Enc. 


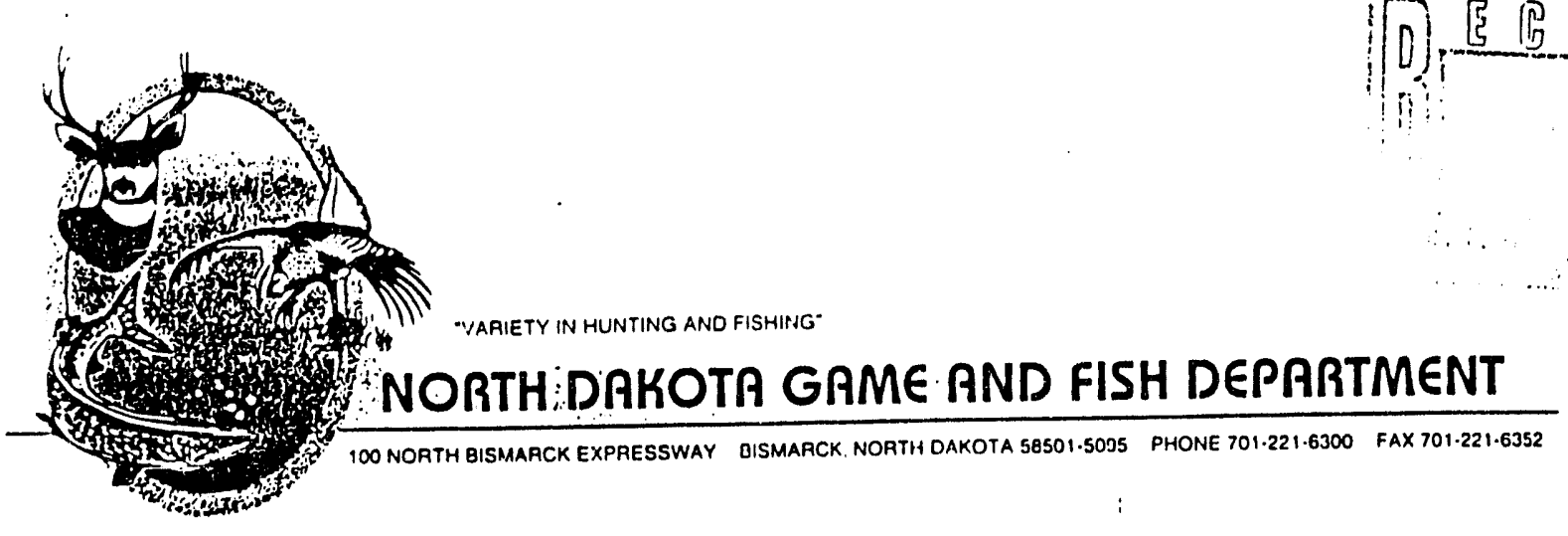

3100

MEMORANDUM

DATE: $\quad$ August 23,1993

TO: Michael Mahlum, Program Administrator Office of Intergovernmental Assistance

FROM: Michael McKenna, Chief IePP

Natural Resources Division

SUBJECT: Hazen Institutional Conservation Program (ICP) Project

The North Dakota Game and Fish Department has reviewed this project and believes that the proposed developinents will have no adverse impacts on wildlife or wildlife habitat, including endangered species.

ir 
Appendix D

Response of the North Dakota State Historical Society

D-1 


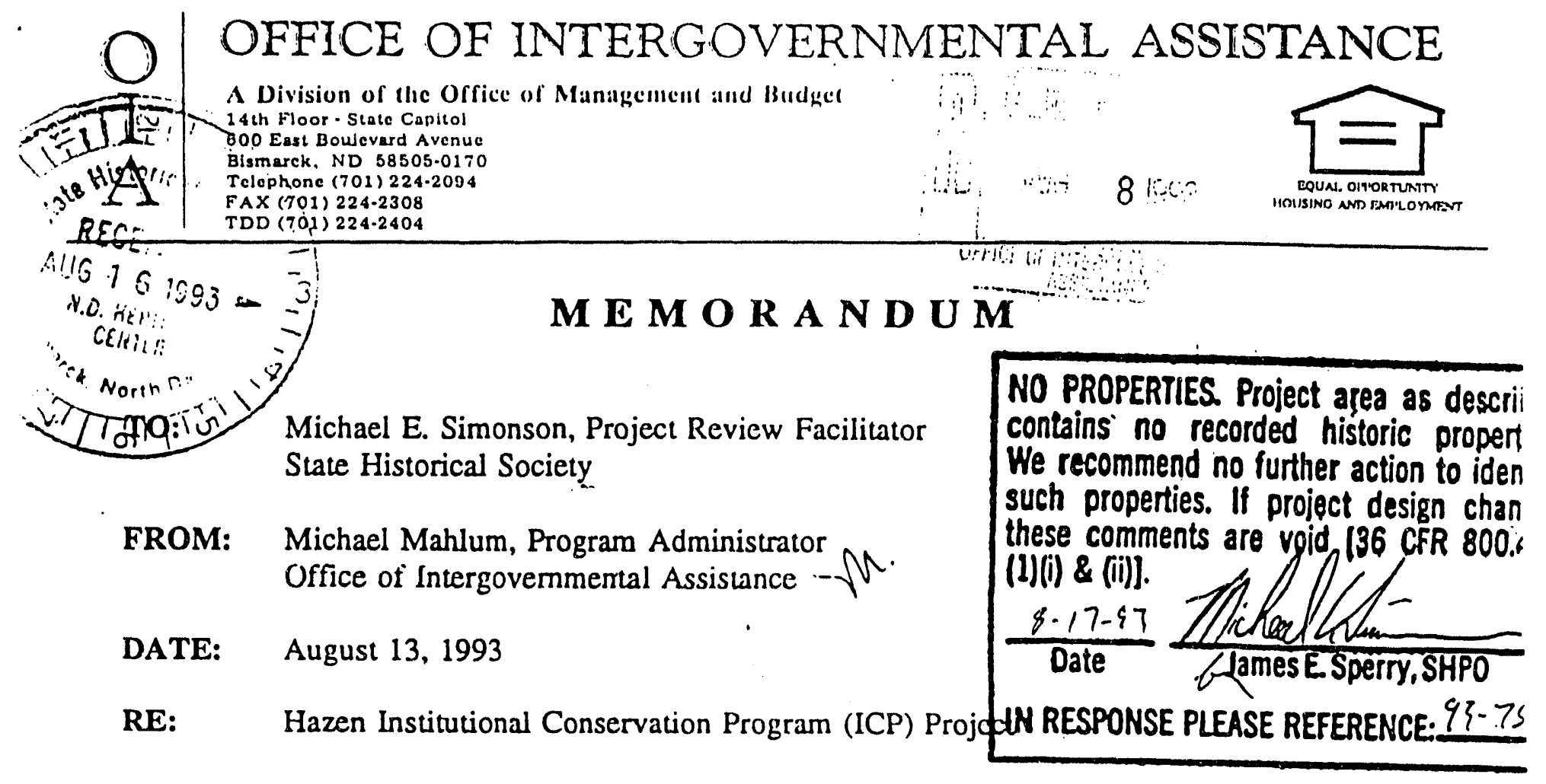

I've been working with the Sakakawea Medical Center in Hazen, which has been awarded a grant to install a coal fired boiler system at their facility.

Before final funding approval can be issued by the US Department of Energy, the institution had to submit an environmental assessment to DOE. The EA which was submitted to DOE was provided to Analytical Services, Inc, a Mary' n consulting firm which provided input into additional information which would be necessary for DOE approval.

In particular, they felt that the project should be submitted to the State Historic Preservation Officer for a letter confirming, whether there were any known resources having historic, architectural, or archaeological significance, including Native American burial grounds or sacred use areas, which would be affected by the proposed action. 1) I have included a map showing the proposed project location, which is in the Gity of $\mathrm{H}$ azen. The plans are to build a steel building of $500-1,000$ square feet to house a boiler and coal bin. The proposed location has been previously disturbed and landscaped, and is located directly adjacent to a parking lot and railroad track.

To the best of my knowledge, there are no properties in the vicinity listed on the National Register of Historic Places, the proposed site is not associated with events which were historically significant or the lives of any people of historical significance, is absent of any structures, seems unlikely to yield historical or prehistorical information or history due to its previously disturt - nature, or is not part of any such historic district.

Could you please notify me if the site has any such historic significance? If you need additional information, please call me at 224-2094.

df

Enc. 
Appendix E

Response of the North Dakota State

Department of Health and Consolidated Laboratories

E-1 
February 8,1993

Mr. Mike Mahlum

Office of Intergovernmental

Assistance

Institutional conservation

Program (ICP)
1200 Missourl Avenue

P.O. Box 5520

Bismarck. North Dakola 58502.5520

Fax $\$ 701.221 .5200$

Re: Sakakawea Medical Center

Dear Mr. Mahlum:

Enclosed is a draft section of the environmental assessment for the proposed coal-fired boller at the Sakakawea Medical Center. This portion of the assessment addresses alr pollution, solld waste (bottom ash), and asbestos.

If you have any questions, please call me.

sincerely,

Tom Bachrnar

Tom Bachman, P.E.

Manager

Alr Quality Management Branch

DIv. of Environmental Engineering

TB:dgg

Enc:

\section{$E-2$}


The new coal-fired boiler system will result in air contaminants being emitted and ash generated. A review was conducted to compare emissions of the existing boiler system with those from the new coal-fired boiler. The review was conducted by the North Dakota Air pollution control Program which is approved by the U.S. EPA. Details are summarized in Table 1 . The results show a coal-fired furnace would increase emissions above those currently released by the fuel oll furnaces. The new coal-fired boller will be exempt from the ND requirement to obtain a Permit to construct and Permit to Operate since 1 ts rated heat input (approximately $4.5 \times 10^{6}$ BTU/hr) is less than the size required to have a permit $\left(10 \times 10^{6}\right.$ BTU/hr) and actual emissions will be less than 25 tons per year of any air contaminant.

Ambient air quality monitoring data in the Hazen area has indicated that the level of air contaminants is weil below the state and Federal Ambient Alr Quality standards. The state Ambient Alr Quality standards are at least as stringent as the Federal standards. The entire state of North Dakota is in attainment with all Federal Ambient Air Quality Standards. Based on the small quantity of emissions, the ND state Department of Health (Alr pollution Control program) expects that the facility will comply with all applicable state and Federal Air pollution Control Rules. The minor amount of emissions is unlikely to cause any adverse effects on plants and animals. The project will release a small amount of carbon dioxide, a gas which is thought to contribute to global warming. However, the overall impact to alr quality from installing the proposed coal-fired furnace is expected to be minor.

Assuming an ash content of 7 percent of the coal, burning 430 tons of lignite per year (based on the Medical Center current energy usage for heat) would produce approximately 26 tons per year of bottom ash. The Health Department's Solid Waste Management Program regulates the disposal of this material in municipal solid waste landfills in North Dakota. Proper disposal of the coal ash in an approved landf111 would prevent degradation of solls, surface water quality, and groundwater quality. The landfill at Hazen, North Dakota is an acceptable facility for the disposal of the bottom ash generated from the proposed coal-fired furnace.

The Sakakawea Medical Center has removed all asbestos-containing material from their facility. Therefore, the disturbance of asbestos material during the installation of the boller is not of concern. 
TABLE 1

SAKAKAWEA MEDICAL CENTER

Alr Contaminant Emissions

(pounds per year)

\begin{tabular}{|c|c|c|c|c|c|c|}
\hline \multirow[b]{2}{*}{ Fue 1 } & \multirow[b]{2}{*}{$\begin{array}{c}\text { Particulate } \\
\text { Matter }\end{array}$} & \multirow[b]{2}{*}{$\begin{array}{l}\text { Sulfur } \\
\text { Oxides }\end{array}$} & \multirow[b]{2}{*}{$\begin{array}{l}\text { Nitrogen } \\
\text { Oxides } \\
\end{array}$} & \multirow{2}{*}{$\begin{array}{l}\text { Carbon' } \\
\text { Monoxide }\end{array}$} & \multicolumn{2}{|c|}{ Hydrocarbons ${ }^{3}$} \\
\hline & & & & & Nonme thane & Methane \\
\hline Fuel ofl system & & & & & & \\
\hline (present usage) & 64 & 2,281 & 640 & 161 & 11 & 7 \\
\hline Coal-Fired System & 8,729 & 10,320 & 2,580 & 4.730 & 559 & 344 \\
\hline
\end{tabular}

1. Based on an average ash content of 78 (as received)

2. Based on an average sulfur content of 0.88 . (as recelved) for coal and 0.58 ior oll.

3. Based on use of an underfeed stoker. 

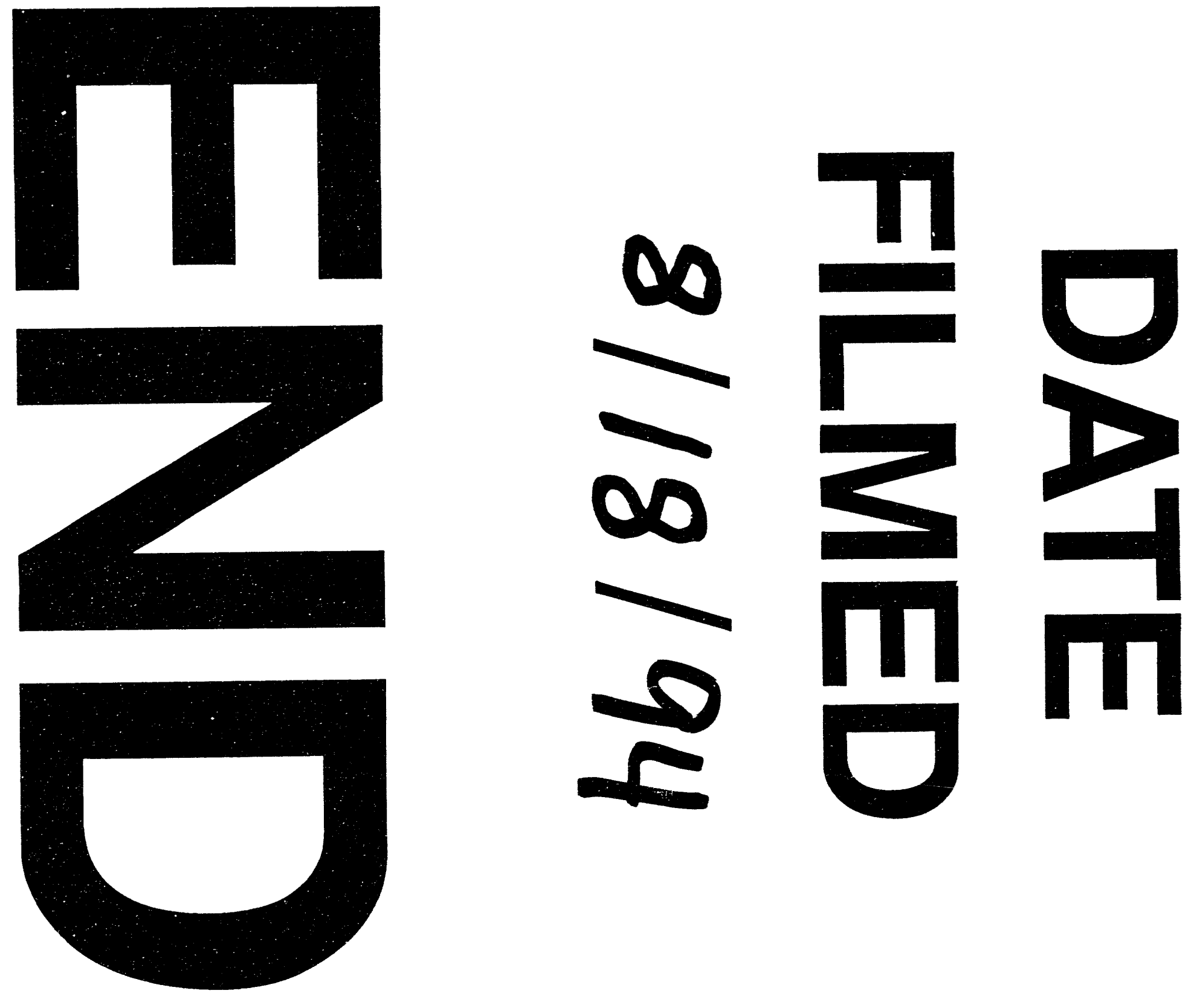


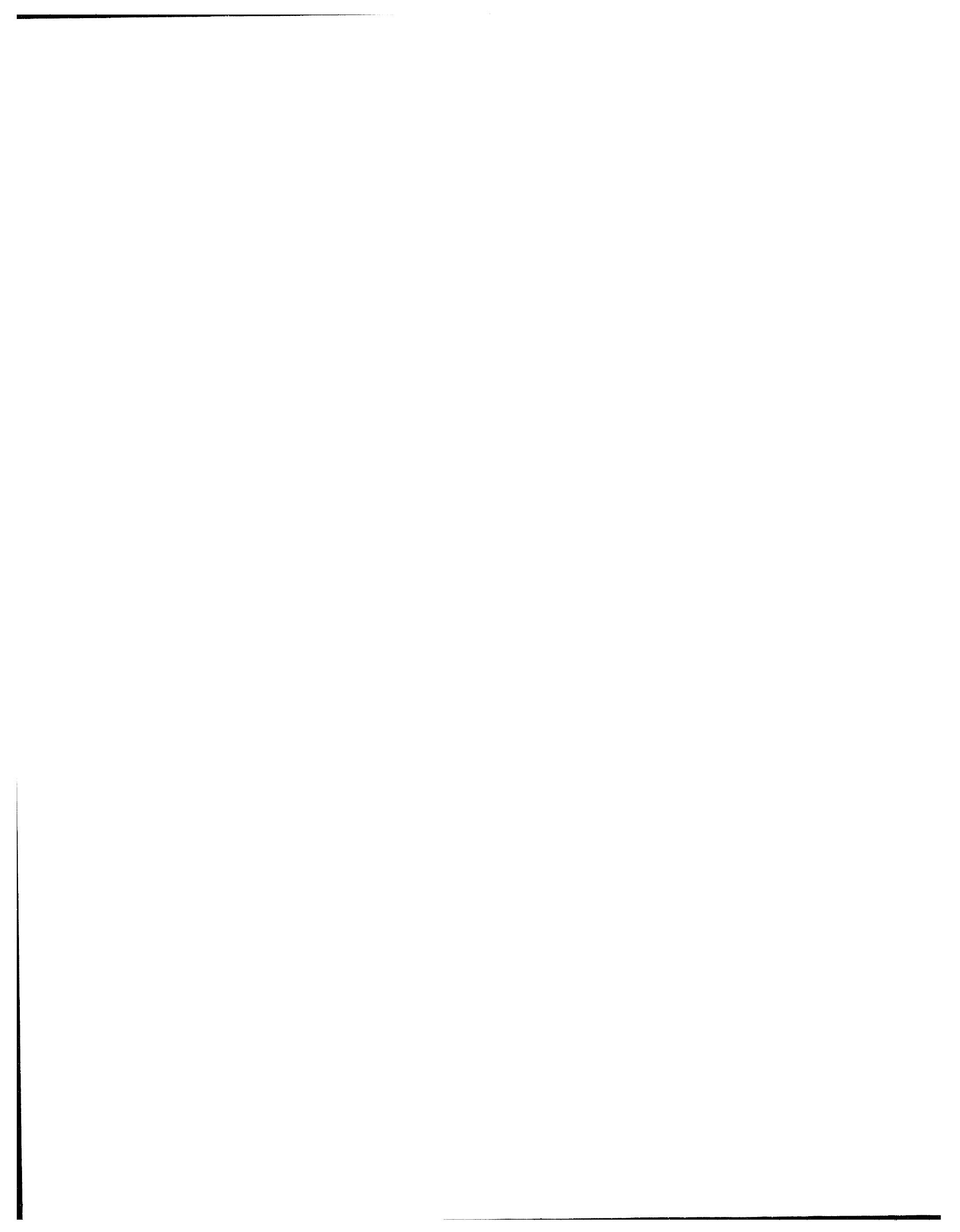

